\title{
DESIGN AND PILOT RUN OF FUZZY SYNTHETIC MODEL (FSM) FOR RISK EVALUATION IN CIVIL ENGINEERING
}

\author{
Hamzah Abdul-Rahman ${ }^{1}$, Chen Wang ${ }^{2}$, Yee Lin Lee ${ }^{3}$ \\ Faculty of Built Environment, University of Malaya, 50603 Kuala Lumpur, Malaysia \\ E-mails:11arhamzah@um.edu.com; ${ }^{2}$ derekisleon@gmail.com (corresponding author); \\ ${ }^{3}$ cipmgroup@gmail.com
}

Received 01 Jul. 2011; accepted 07 Jul. 2011

\begin{abstract}
Most of the current construction risk assessment tools deliver unsatisfactory results because the prerequisite for their effective applications rely on the availability of high quality data especially during the early stage of a project. Unfortunately, such data are limited, ambiguous or even not exist due to the great uncertainty inherent in construction projects. Based on Fuzzy Synthetic Analysis (FSA), a model development team was formed among construction engineers, IT professionals, and Mathematicians in developing a holistic risk assessment model to estimate the construction risks especially for the situations with incomplete data and vague environments. Through qualitative scales defined by triangular fuzzy numbers used in pairwise comparisons to capture the vagueness in the linguistic variables, a risk assessment model using Analytic Hierarchy Process (AHP) was developed. The Pilot Run revealed the developed Fuzzy Synthetic Model (FSM) could accelerate the decisionmaking process and provide optimal allocation of project resources to mitigate possible risks detrimental to the success of a project in terms of time, cost, and quality.

Keywords: Fuzzy-AHP, Fuzzy Multi-criteria Decision Analysis, Triangular Fuzzy numbers, risk assessment, Fuzzy linguistic scale.

Reference to this paper should be made as follows: Abdul-Rahman, H.; Wang, C.; Lee, Y. L. 2013. Design and pilot run of fuzzy synthetic model (FSM) for risk evaluation in civil engineering, Journal of Civil Engineering and Management 19(2): 217-238.
\end{abstract}

\section{Introduction}

In the past few years, several quantitative-based approaches have been introduced for construction risk management such as Fault Tree Analysis, Monte Carlo Analysis, and Sensitivity Analysis (Ahmed et al. 2007). These sophisticated methods could deal with massive numerical data to deliver reliable statistical risk result. However, the availability of high quality data especially during the early stage of projects is a prerequisite for their effective applications (Sii, Wang 2003). Unfortunately, such data are limited, ambiguous or even not exist due to the great uncertainty inherent in construction projects. Therefore, the quantitative approaches could not suitably and effectively handle the risks (Franceschini, Galleto 2001).

In the mid of 1960s, Professor Lofti Zadeh introduced fuzzy logic to mathematically represent the uncertainty and vagueness inherited in the real world (Zadeh 1965). Scholars have presented the use of fuzzy logic in construction projects such as duration management (Zieliński 2005; Chen, Hsueh 2007), cost estimation (Cheng et al. 2010; Idrus et al. 2011), risk management (Zhang, Zou 2007; Lee, Lin 2010), safety management (Dağdeviren, Yüksel 2008), supply chain management (Chen, Huang 2006; Wei et al. 2007) and earned value management (Naeni et al. 2011). The extensive application of Fuzzy logic in the realm of construction demonstrated its easiness to be developed, understood and applied (Kasabov 1996). According to Dweiri and Kablan (2006), fuzzy logic is an excellent tool that could greatly improve the chances of achieving a better quality construction project. Eventually, it resulted in superior project performance and subsequent project success in the field of construction. Fuzzy logic is a tool to deal with decision-making environments characterized by vagueness, impression, and subjectivity (G., Bojadziev, M. Bojadziev 2007). The integration of Fuzzy logic in project risk management could give rise to satisfactory results by effectively addressing the uncertainties and subjectivities associated with construction activities. Moreover, fuzzy logic provides a more realistic way than traditional mathematical models to cope with problems that are vague in nature (Heshmaty, Kandel 1985). Based on Fuzzy Set Theory (FST), this study intends to develop a holistic risk assessment model using to estimate 
the construction risks especially for situations with incomplete data and vague environments. This paper introduces the principles and algorithm of its risk assessment framework. Further, a Pilot Run for the developed Fuzzy Synthetic Model (FSM) is presented.

\section{Fuzzy logic and FST in construction risk management}

Fuzzy Set Theory (FST), or, Fuzzy Logic, resembles human ability in inferring an approximate answer to a question based on a store of knowledge that is vague, inexact, incomplete, or not totally reliable (Zadeh 1978). In other words, Fuzzy logic simulates the way human brain works to solve real-world problems (Yager 2002) such as in forecasting, decision making, and management, which are characterized by uncertainty, impression, and subjectivity (G. Bojadziev, M. Bojadziev 2007; Negnevitsky 2004).

No construction project is risk free. Risk can be managed, minimized, shared, transferred or accepted. It cannot be ignored (Latham 1994). Over years, scholars have proposed a variety of risk management methodologies for real practise, yet most of them are similar in process, following a systematic three-step approach: identify, assess, and mitigate construction risks (Flanagan, Norman 1993; Berkeley et al. 1991; Lyons, Skitmore 2004). Out of the three steps, risk assessment process is the most controversial issue (Baloi, Price 2003). Meantime, there were a few research studies attempted to use FST to formalize subjectivity issues in the construction risk analysis. One of the earliest FST-based approaches was outlined by Nguyen (1985) to solve decision-making problems during the selection of bid contracts. Kangari and Riggs (1989) presented a composited fuzzy-knowledgebased system to analyze risk but revealed the limitations of probability-based approach in risk assessment process: difficult in the quantifying qualitative data, where precise data is unavailable in real situation. This issue activated the subsequent courses of exploration to investigate the fatal weakness of the probability approach in construction project risk evaluation.

Being pioneers in adopting Analytic Hierarchy Process (AHP) within construction decision problem analysis, Mustafa and Al-Bahar (1991) assessed risks through the appraising of probability and impact of risk occurrence. AHP was developed by Saaty (1980, 1990) to cope with complex decision-making problems. AHP was applied by Dey et al. (1994) and Riggs et al. (1994) to combine objective and subjective data as an attempt to analyze cost risk where risk was modelled as Probability-Impact (P-I). Zhi (1995) proposed using AHP to evaluate risk in international projects. Chun and Ahn (1992) on the other hand, integrated FST into risk analysis model to quantify the imprecision inherent in the accident progression event trees. Using FST, Paek et al. (1993) established a risk algorithm for the assessment of bidding price of construction projects. Wirba et al. (1996) applied FST to capture human reasoning in the identification and evaluation of risks.

In the 2000s, since the outset of millennium, there have been rigorous investigations to efficaciously model and evaluate the construction project risk. Risk began to be dealt comprehensively using multi-criteria decision-making (MCDM) techniques to facilitate the complex decision-making process in risk assessment. Despite the availability of many others techniques, both AHP and FST turned out as the most favoured methodologies in handling ill-defined subjective problems. They were perceived as the best ever approaches in problem-solving that encompassing multiple criteria. For instance, Hastak and Shaked (2000) proposed an AHP model to assess the risk of overseas projects. Baccarini and Archer (2001) used both the probability and impact risk parameters to rank project risks. Likewise, Jannadi and Almishari (2003) attempted to analyze risks concerned with project activities. Risk is modelled by probability and "exposure" to all hazards of an activity. Ward and Chapman (2003), however, criticized on the $\mathrm{P}-\mathrm{I}$ risk model that it yielded unnecessary uncertainty by oversimplifying the estimation of risk impact and probability.

Zhang (2007) expounded the deficiencies of the P-I grid. Alternatively, "project vulnerability" is introduced to enhance the recognition of risk consequences. In the same year, Cagno et al. (2007) used the $\mathrm{P}-\mathrm{I}$ risk model to quantify the cost risk by determining the sources of risks, affected activities, and risk owners. Besides, a three-dimensional risk model called Significance-Probability-Impact was presented where "significance" is defined as the degree to which a practitioner assesses risk intuitively. Recently, Cioffi and Khamooshi (2009) generated a probabilitybased model to estimate the overall risk impact on contingency budget. Based on both AHP and decision tree, Dey (2001) sought to effectively manage construction cost risk as early as on the inception stage. In addition, Dikmen et al. (2007a) adopted AHP to appraise uncertainties and opportunities of the overseas construction projects. The overall project risk level was computed by multiplying the relative impact and the relative likelihood of each risk. All the individual risk impacts were summed up to obtain final score. In contrast, Zayed et al. (2008) applied AHP to allocate weighs to risks before calculating the risk level. Some researchers attempted to integrate FST into risk assessment process. They focus mainly on the improvement of the efficiency of the conventional risk assessment tools, though rather new tools have been proposed by Huang et al. (2001) and Cho et al. (2002). Using the risk hierarchical breakdown structure, Tah and Carr (2000) proposed a fuzzy qualitative risk assessment model, where experts' subjective judgments were captured within the model 
to assess the risk impact. Noticing the drawback of FST in such an application, Tah and Carr (2001) proposed a new combination rule in the aggregation process of a predominant risk factor. Choi et al. (2004) developed a FST model to analyze risks using objective probabilities, subjective judgments, and linguistic variables. Similarly, Shang et al. (2005) designed a Fuzzy-based mechanism for risk assessment for the conceptual design stages of a construction project. Zheng and Ng (2005) applied FST to assess the cost and budget in construction projects.

In addition, Thomas et al. (2006) generated a fuzzy fault tree to enhance risk assessments by considering the opinions of different experts. A fuzzy decision-making model was designed by Wang and Elhag (2007) for a bridge construction project. The model evaluates risks based on the likelihood and consequences of occurrence. In consideration of overseas projects, Dikmen et al. (2007b) adopted an influence diagrams to create a fuzzy risk assessment approach to prioritize risk based on cost excess of budget. Meanwhile, Zeng et al. (2007) used FST to cope with uncertainty whereas AHP was applied to decompose and to prioritize multiple risk sources. Risks were first described in linguistic values and later transformed into fuzzy numbers. In the most recent, Lee and Lin (2010) suggested the use of AHP in fuzzy risk assessment in construction projects. Linguistic terms and Fuzzy numbers were directly adopted, rather than the use of quantitative data in risk assessment process. Likewise, Nieto-Morote and Ruz-Vila (2011) presented a risk assessment framework based on the FST, which could effectively capture the subjective judgements decompose large number of risks. The most notable distinction was the adoption of a risk discrimination algorithm to solve the inconsistencies in the computation process. Table 1 overviews the developed risk assessment techniques from 1980s till the year of 2011.

\section{Fuzzy Analytic Hierarchy Process (Fuzzy-AHP)}

Fuzzy-AHP has been extensively adopted to solve qualitative MCDM problems in the context of construction risk assessment. Together with hierarchical structure analysis, FST could excellently handle the ambiguity inherited in the conventional data evaluation process, which encompasses identification, evaluation, and prioritization of the MCDM problems (Chen 2001). One of the significant aspects of FuzzyAHP is its ability in solving ill-defined and vague problems in construction projects and reaching a reliable final decision (Zeng et al. 2007; Zhang et al. 2002; An et al. 2005). Being proven to be more advanced and efficacious in tackling complex MCDM problems, Fuzzy-AHP generally follows a process, structured in a three-step approach, namely: a) generation of risk hierarchy tree; b) pairwise comparison to establish fuzzy comparison matrix; c) fuzzy prioritization of criteria.

\subsection{Generation of risk hierarchy tree}

Taxonomy of a typical hierarchy tree associated with construction project risks is shown in Figure 1. The complex decision problems can be formulated in the form of simple hierarchy tree. The overall goal is placed at the highest level. The criteria affecting the goal are located in the middle levels. The lowest level presents the decision options. Before the hierarchy tree is structured, different risk factors have to be exhaustively recognized. Usually, the construction practitioners have intuitive methods of recognizing a risk source. This is in accordance with the statement of Wang et al. (2004) that experts prefer to intuitively identify risks using experience and knowledge gained from previous contracts. There are, anyhow, some formal risk identification tools such as Checklist, Influence Diagrams, Cause and Effect Diagram, Failure Mode and Effect Analysis, and Fault Trees Analysis (Zavadskas et al. 2010; Tah, Carr 2000).

Nevertheless, large construction projects tend to adopt formalized risk identification tools, and vice versa. All the sources of uncertainties identified are classified within the hierarchy tree structure so that they can be thoroughly evaluated. Various risk classification methods are shown in Table 2. The methods adopted to classify construction risks depend largely on the nature of a project as well as the management skills of experts. Once the decomposition of risk problems into a hierarchy tree is completed, risk assessment process is carried out to determine the relative importance, dominance or preference of the decision criteria with regards to the goal of the problems.

\subsection{Pairwise comparison to establish Fuzzy comparison matrix}

The importance weighs of criteria is determined in the pairwise comparison manner. Anyhow, the difference between pairwise comparison process in Fuzzy-AHP and normal AHP is in the use of Fuzzy comparison scale, where Fuzzy numbers are integrated into the original comparison scale to substitute the nine exact numbers in Fuzzy-AHP. Experts could intuitively express their preferences as the Fuzzy numbers could accurately describe the expert's verbal judgments in the process Zadeh (1965). The Fuzzy comparison scale works excellent in capturing the subjective experience and knowledge of experts through the application of the Fuzzy numbers (Chang, Yeh 2002; Kahraman et al. 2004) within Fuzzy-AHP. Using the advanced comparison scale, experts could express their judgments using natural languages such as "equally important" and "absolutely more important" which 
Table 1. Overview of risk assessment approaches from 1980s to 2000s

\begin{tabular}{|c|c|c|c|c|}
\hline \multirow{2}{*}{$\begin{array}{l}\text { Period of } \\
\text { Time }\end{array}$} & \multirow[b]{2}{*}{ Author } & \multirow[b]{2}{*}{ Risk Assessment Approach/Methodology } & \multicolumn{2}{|c|}{$\begin{array}{l}\text { Assess Risk against } \\
\text { Project Objective }\end{array}$} \\
\hline & & & Yes & No \\
\hline \multirow[t]{5}{*}{$1980 \mathrm{~s}$} & Chapman and Cooper (1983) & PERT, decision trees \& probability distributions & Time & \\
\hline & Cooper et al. (1985) & $\begin{array}{l}\text { Risk breakdown structure \& variation } \\
\text { distribution }\end{array}$ & Cost & \\
\hline & Nguyen (1985) & FST & Cost & \\
\hline & Franke (1987) & Probability theory & Cost & \\
\hline & Kangari and Riggs (1989) & FST & & $\sqrt{ }$ \\
\hline \multirow[t]{12}{*}{ The 1990s } & Yeo (1990) & Probability, Range estimates method \& PERT & Cost & \\
\hline & Mustafa and Al-Bahar (1991) & AHP & & $\sqrt{ }$ \\
\hline & Diekmann (1992) & Probability & & $\sqrt{ }$ \\
\hline & Chun and Ahn (1992) & FST \& event trees & & $\sqrt{ }$ \\
\hline & Paek et al. (1993) & FST & Cost & \\
\hline & Dey et al. (1994) & AHP & Cost & \\
\hline & Riggs et al. (1994) & AHP & Cost \& time & \\
\hline & Zhi (1995) & AHP & & $\sqrt{ }$ \\
\hline & Williams (1995) & Probability & Quality & \\
\hline & Wirba et al. (1996) & FST & & $\sqrt{ }$ \\
\hline & Tavares et al. (1998) & Stochastic model & Cost \& time & \\
\hline & Mulholland and Christian (1999) & Probability \& PERT & Time & \\
\hline \multirow[t]{24}{*}{ The $2000 \mathrm{~s}$} & Hastak and Shaked (2000) & AHP and Probability & & $\sqrt{ }$ \\
\hline & Tah and Carr (2000) & FST & & $\sqrt{ }$ \\
\hline & Dey $(2001)$ & AHP \& decision trees & Cost & \\
\hline & Tah and Carr (2001) & FST & & $\sqrt{ }$ \\
\hline & Baccarini and Archer (2001) & Probability & $\begin{array}{l}\text { Cost, time \& } \\
\text { quality }\end{array}$ & \\
\hline & Cho et al. (2002) & FST & & $\sqrt{ }$ \\
\hline & Ward and Chapman (2003) & 6-steps minimalist approach & & $\sqrt{ }$ \\
\hline & Baloi and Price (2003) & FST & Cost & \\
\hline & Jannadi and Almishari (2003) & Probability & Time & \\
\hline & Choi et al. (2004) & FST & & $\sqrt{ }$ \\
\hline & Shang et al. (2005) & FST & & $\sqrt{ }$ \\
\hline & Dikmen et al. (2007a) & AHP & & $\sqrt{ }$ \\
\hline & Cagno et al. (2007) & Probability & Time & \\
\hline & Zhang (2007) & Probability & & $\sqrt{ }$ \\
\hline & Wang and Elhag (2007) & FST & & $\sqrt{ }$ \\
\hline & Zeng et al. (2007) & FST \& AHP & & $\sqrt{ }$ \\
\hline & Zheng and $\mathrm{Ng}(2005)$ & FST & Cost \& time & \\
\hline & Zhang and Zou (2007) & FST \& AHP & & $\sqrt{ }$ \\
\hline & Dikmen et al. (2007b) & FST \& AHP & Cost & \\
\hline & Han et al. (2008) & Probability & Cost & \\
\hline & Zayed et al. (2008) & AHP & & $\sqrt{ }$ \\
\hline & Cioffi and Khamooshi (2009) & Probability theory & Cost & \\
\hline & Lee and Lin (2010) & FST & & $\sqrt{ }$ \\
\hline & Nieto-Morote and Ruz-Vila (2011) & FST \& AHP & & $\sqrt{ }$ \\
\hline
\end{tabular}

are directly corresponding to Fuzzy scale of $(1,1,1)$ and $(17 / 2,9,19 / 2)$, respectively. Reciprocal scale is adopted whenever the later criterion $j$ is more dominant than the former criterion $i$. As such, the expert no longer face difficulty in giving fixed judgments, which is in the form of exact numbers, but rather interval judgments, which is in the form of Fuzzy numbers. There are various types of Fuzzy numbers proposed in Fuzzy comparison scale, yet the triangular and trapezoidal shapes are the most frequently used membership functions in construction risk analysis practice due to their simplicity in application (An et al. 2005). They have been proven to be able to efficaciously formulate problems where the data available is of subjective and vague (Kahraman et al. 2004; Chang et al. 2007). In comparison, the triangular shape membership functions are the most often used in representing the Fuzzy numbers (Karsak, Tolga 2001) 


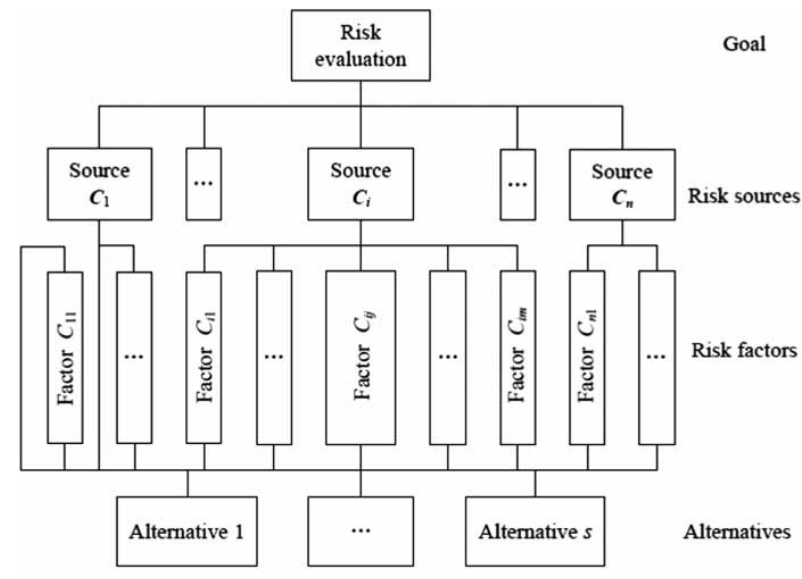

Fig. 1. Theoretical model of risk evaluation (Sun et al. 2008)

in the Fuzzy comparison scales. Likewise, Pedrycz (1994) expressed that a triangular Fuzzy number (TFN) is the easiest and simplest way to approach the convex functions. Moreover, if the pairwise comparison process involves group-decision-making, the experts' preferences on particular criterion have to be aggregated. This is because experts with different background and experience would have different preference on a particular criterion. Hence, it needs to aggregate the individual preferences into the group preference to average out the relative importance weightings of the criteria. The aggregation process is carried out for every criterion, until all criterions have their own group preferences. The groups preferences, which are remain in Fuzzy numbers, are arranged in a systematic manner to yield a Fuzzy comparison matrix. Pairwise comparison is used to calculate the relative importance weighing of each risk criterion with the incorporation of Fuzzy numbers to capture the sub-

Table 2. Previous introduced risk classification methods

\begin{tabular}{|c|c|c|c|}
\hline No. & Author & $\begin{array}{c}\text { Risk } \\
\text { Classification } \\
\text { method }\end{array}$ & $\begin{array}{l}\text { Grouping risk } \\
\text { based on: }\end{array}$ \\
\hline 1 & $\begin{array}{l}\text { Cooper and } \\
\text { Chapman } \\
(1987)\end{array}$ & $\begin{array}{l}\text { Nature and } \\
\text { magnitude }\end{array}$ & $\begin{array}{l}\text { Primary and } \\
\text { secondary risk }\end{array}$ \\
\hline 2 & $\begin{array}{l}\text { Wirba et al. } \\
\text { (1996) }\end{array}$ & $\begin{array}{l}\text { Risk- } \\
\text { breakdown } \\
\text { structure }\end{array}$ & $\begin{array}{l}\text { Minor and major } \\
\text { risks }\end{array}$ \\
\hline 3 & $\begin{array}{l}\text { Tah and Carr } \\
(2000)\end{array}$ & $\begin{array}{l}\text { Risk- } \\
\text { breakdown } \\
\text { structure }\end{array}$ & $\begin{array}{l}\text { External and } \\
\text { Internal factor }\end{array}$ \\
\hline 4 & $\begin{array}{l}\text { Dikmen et al. } \\
\text { (2007a) }\end{array}$ & $\begin{array}{l}\text { Influence } \\
\text { Diagram }\end{array}$ & $\begin{array}{l}\text { Project risk \& } \\
\text { Country risk }\end{array}$ \\
\hline 5 & $\begin{array}{l}\text { Zayed et al. } \\
\text { (2008) }\end{array}$ & $\begin{array}{l}\text { Hierarchy } \\
\text { structure }\end{array}$ & $\begin{array}{l}\text { Macro and micro } \\
\text { level }\end{array}$ \\
\hline 6 & $\begin{array}{l}\text { Nieto-Morote } \\
\text { and Ruz-Vila } \\
(2011)\end{array}$ & $\begin{array}{l}\text { Hierarchy } \\
\text { structure }\end{array}$ & $\begin{array}{l}\text { Responsibility of the } \\
\text { Construction } \\
\text { practitioners }\end{array}$ \\
\hline
\end{tabular}

jective expert's judgments in the process. The output is a Fuzzy comparison matrix (Ding, Liang 2005; Xu, Chen 2007).

\subsection{Fuzzy prioritization of criteria}

Since Saaty (1980) had proposed the AHP, many researchers enrolled in the extension of the eigenvector priority method to overcome its inconsistency in producing results. As an attempt to produce reliable final priority weighs, researchers adopted different types of Fuzzy prioritization approaches, for instance, the earliest attempt in prioritizing fuzzy weighs was accomplished by van Laarhoven and Pedrycz (1983) in which triangular fuzzy numbers were compared according to their membership functions. Likewise, Buckley (1985) used trapezoidal fuzzy numbers to integrate the fuzzy priorities of comparison ratios. A new approach called Fuzzy Synthetic Analysis (FSA) for computation of a sequence of weigh vectors (Chang 1996) suggested the application of extent analysis method for the synthetic extent values of the Fuzzy pairwise comparisons. The term "synthetic" expresses the process of evaluation whereby several individual criterions of an evaluation are synthesized and aggregated to a final form. Despite the diversity of Fuzzy prioritization approaches, FSA is the most abundant used method in the literatures indicating its popularity in prioritizing decision variables. It has been perceived as the best prioritizing method due to its simple and easy in application (Chan, Kumar 2007).

\section{Methods and procedures in developing FSM}

To appropriately conduct the qualitative technique in the development of FSM, a developing team was established consisting of construction engineers, IT professionals, risk managers, and mathematicians. Owing to the nature of the developers where their experiences, perceptions, and opinions are necessities to the enhancement of the model, the qualitative approach was adopted in this study. The qualitative technique enables on-the-spot directness to the information in which rapid, immediate response could be obtained from the elites, where it is not possible when the quantitative technique such as questionnaire surveys are conducted. The developing team consists of a range of experts of different specialties, whose detailed information regarding their contribution towards the birth of FSM is summarised in Table 3.

The use of probability theory to deal with the construction project of one-time characteristic complicates the risk analysis process. Conventional approaches are impractical in those real situations where high quality data are absent yet they could not effectively deal with the subjective human assessments, for instance, the fixed scale of 1-9 used in the pairwise comparison process is incapable to 
Table 3. Developers' profiles and roles in the development of FSM

\begin{tabular}{|c|c|c|c|c|c|c|}
\hline Developer & Age & Gender & Location & Specialty/Area & & in Developing the FSM \\
\hline A & 52 & Male & $\begin{array}{l}\text { Kuala } \\
\text { Lumpur }\end{array}$ & $\begin{array}{l}\text { Project } \\
\text { Monitoring }\end{array}$ & $\begin{array}{l}\text { Preliminary step: } \\
\text { Selection of Risk } \\
\text { Analysis Approach }\end{array}$ & $\begin{array}{l}\text { Considering the limitation of } \\
\text { conventional AHP models in yielding } \\
\text { reliable results owing to their inability to } \\
\text { effectively quantify subjective data, } \\
\text { Developer A aroused the idea of } \\
\text { integrating fuzzy tools into the AHP to } \\
\text { further enhance the efficiency and } \\
\text { practicability of the model. Accordingly, } \\
\text { the team decided to synthesized FST, } \\
\text { which was proven as an excellent tool to } \\
\text { capture uncertain and subjective } \\
\text { qualitative data in decision-making } \\
\text { process, within the developed model. }\end{array}$ \\
\hline
\end{tabular}

B

$\begin{array}{lll}37 \text { Male } & \text { Kuala } & \text { Fuzzy Model } \\ & \text { Lumpur } & \text { Development }\end{array}$

C

33 Male

Selangor

Construction Risk Preliminary step:

Selection of Risk

Analysis Approach

Preliminary step:
Appearance of Model

Developer B adopted FST in the developed model although the concept was unfamiliar in the context of construction industry. Moreover, Developer B mapped how to present the model holistically. Important elements such as mathematical formulae have been added into the model to enable an explicit picture of the whole structure. The model so that could be presented in a simple but comprehensive way.

Developer C captured and incorporated the subjective data of construction processes into the risk analysis techniques to increase the consistency for risk management. The real construction rarely adopt formal risk analysis tools. The only technique applied in the medium and small firms is informal technique such as rule of thumb.

$\mathrm{D}$

36 Female Kuala

Lumpur

Construction IT

Application

Step 2 \& 6: Selectio
Risk Parameters

Step 1: Range of

Construction Expertise

Step 2: Risk Identification
Step 2: Risk

Identification f Developer D provided the risk parameters used during the evaluation of risks. Both the risk likelihood and risk severity have been considered in evaluating the risk impact to avoid misleading solutions. For example, a risk with high likelihood of occurrence is not necessarily with high level of severity when it occurred.

Developer E produced risk hierarchy trees in different perspectives. Besides, Developer E identified the differences in risk management skills according to the positions of construction practitioners.

Developer F multiplied the risk parameters in the analysis to calculate the final risk impact of a particular risk.

Developer $\mathrm{G}$ identified the risks based on the type and nature of projects. Besides, Developer $\mathrm{G}$ figured out the risk identification methods used in the model development. 
Table 3 (Continued)

\begin{tabular}{|c|c|c|c|c|c|c|}
\hline Developer & Age & Gender & Location & Specialty/Area & Role & in Developing the FSM \\
\hline $\mathrm{H}$ & 46 & Male & $\begin{array}{l}\text { Kuala } \\
\text { Lumpur }\end{array}$ & $\begin{array}{l}\text { Construction Risk } \\
\text { Modelling }\end{array}$ & $\begin{array}{l}\text { Step 2: Project } \\
\text { Objectives } \\
\text { Step 3: AHP's } \\
\text { Comparison Method }\end{array}$ & $\begin{array}{l}\text { Developer } \mathrm{H} \text { measured risk impacts with } \\
\text { regards to project objectives such as } \\
\text { time, cost, and quality during the risk } \\
\text { analysis process. } \\
\text { Developer H applied Pairwise } \\
\text { Comparison process within the developed } \\
\text { model, where the risks were compared } \\
\text { to determine which one was more } \\
\text { dominance than the others in a project. }\end{array}$ \\
\hline I & 51 & Female & $\begin{array}{l}\text { Kuala } \\
\text { Lumpur }\end{array}$ & Mathematician & $\begin{array}{l}\text { Step } 4 \text { \& 5: } \\
\text { Mathematical } \\
\text { Formulae }\end{array}$ & $\begin{array}{l}\text { Developer I embedded the mathematical } \\
\text { formulas into the developed FSM. }\end{array}$ \\
\hline
\end{tabular}

describe the interval judgment of experts. The authors adopted the Fuzzy-AHP technique as the decisionmaking framework for construction risk analysis in the developed model since the Fuzzy-AHP allows a more accurate description of the subjective data, where the fuzzy pairwise comparisons are more rational in reflecting experts' uncertain judgments than crisp one. Such a model could facilitate the decision-making process, where the complex uncertainty inherited in subjectivity is able to be captured and mitigated optimally. The project performance is significantly affected by construction risks in concerns of cost, time, and quality. The developed FSM is to holistically solve multi-criteria complex problems in the real practice of construction. The algorithm of the proposed model consists of six phases, which are discussed as follows.

\subsection{Establishment of risk assessment team}

Owing to the large burdens during the project risk analysis, the decision-making process was conducted by a group of risk assessment experts. Due to their different background, experience, and knowledge, each expert in the risk assessment team has different impacts on the final decision. The experts with higher degree of knowledge and more related experience on the targeted project have more substantial impact in the risk assessment process so that their contribution factors are given more weigh in the model. This is due to the reason that the final result is more consistent as the risk analysis process is undertaken comprehensively by different experts with various competencies. The contributions factors are used to determine the weighing for different evaluators. Basically, the relative weighing of the experts is determined by their competence on the basis of their experience, knowledge, and expertise related to the targeted project. The formulas for contribution factors are presented in Section 5. The risk assessment team is responsible to classify and to structure all potential risks within a hierarchy tree in the next step.

\subsection{Structure a hierarchy tree}

Structuring of a hierarchy tree aims to decompose the goal into adequate details in which all the criteria could be thoroughly assessed. Generally, the top level of the hierarchy tree is the overall goal of the decision problem. In the context of construction risk analysis, the goal is defined as risk evaluation. The subsequent levels present the general risk sources, then their specific risk factors, which are evaluated. The lowest level is the alternative of decision options, with regards to the goal, which are determined based on the kind of results desired in the end of analysis. To determine the decision criteria, it entails the understanding of the underlying factors impacting the goal. Hence it is essential to investigate all potential sources of uncertainty likely to affect a project. The recognized risks are classified in a way that the risks with similar characteristics are grouped together in the hierarchy. The construction uncertainty is commonly modelled based on the integration of two risk parameters: a) the probability of occurrence and b) severity of risk impact. The hierarchy tree was constructed as shown in Figure 2. The complex decision problems were structured within a simple hierarchical structure, where the decision criteria were placed comprehensively into five levels. The top level is defined as "Construction Project Risks" to reflect the overall goal. It is followed by two risk parameters that serve as the evaluation basis for risks. The third level is where all major risk sources are located, with their respective risk factors in the subsequent level. The lowest level presents the project objectives including time, cost, and quality.

As illustrated in Figure 2, the general risks and their specific sub-factors are located respectively in the third and the fourth level. Eventually, the project objectives such as time, cost, and quality are placed in the bottom level. It could mitigate the uncertainty depending on the relative risk impact towards the project objective. Compromises such as targeted budget, good scheduled time, and high project quality 


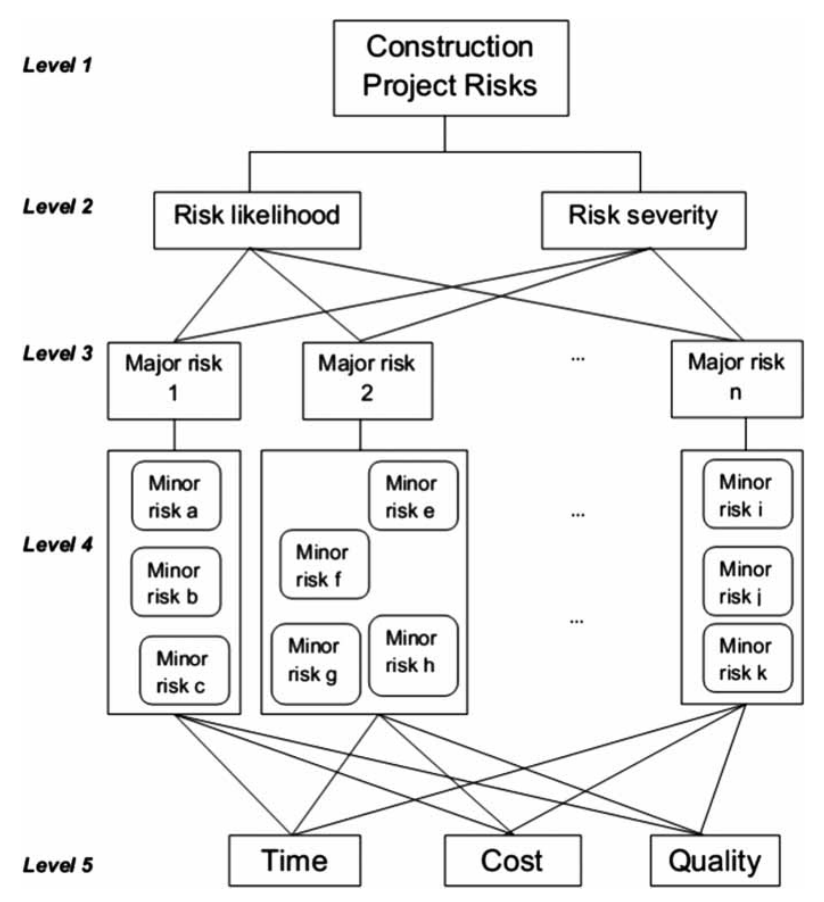

Fig. 2. Risk likelihood and risk severity

are guaranteed when all the project objectives are accomplished.

\subsection{Pairwise comparison using Fuzzy comparison scale}

The risk assessment process is carried out once the hierarchy tree is established. Most frequently there are multiple contradicting risk sources existing in a project. This complicates the decision-making process as the experts need to consider various criteria simultaneously. Hence, it is a necessity to prioritize risks for further attention. To do so, the experts need to firstly determine the relative weigh of each criterion in the same hierarchy, via pairwise comparison process, so that their relative priority weighs could be calculated. The greatest advantage of pairwise comparison is that the experts are allowed to focus on the comparison of just two objects, which makes the observation as free as possible from extraneous influences. To systematically capture the valuable subjective judgments of experts in the risk analysis, Fuzzy comparison scale is proven to be accurate and intuitive in reflecting the qualitative judgments where decision makers could specify preferences in the form of natural language regarding the importance of each criterion. The most common used Fuzzy numbers are both the triangular and trapezoidal Fuzzy number (TFN). In this study, the simplest form of TFN was applied for representing the linguistic judgments, as TFN was sufficient to produce a reliable result. The fuzzy scale of TFN is intuitively easy to use and to calculate so that it was adopted to improve the pairwise comparison process.

\subsection{Aggregation of individual TFNs into group TFN}

Every individual in the risk assessment team has a TFN preference for criterion in the hierarchy tree. The individual TFNs of particular criterion should be aggregated into the group TFN preference. The rationale of this step is to integrate all the individual TFN preferences for particular criterion so that the Fuzzy comparison matrices remain consistent. The aggregation process is completed once the individual TFNs of every criterion in the hierarchy tree are converted into group TFN. All group TFNs are arranged in a matrix structure, which is called "Fuzzy comparison matrices". Consequently, the relative priority weigh of each criterion was calculated using the Fuzzy prioritization method in the next step.

\subsection{Calculation of priority weighs at different hierarchy level}

It is usually not possible to address all risks with a same degree of attention, as resources available for risk management are limited. Concentration on risks with higher priority is essential for efficient risk management. This step aims to calculate the relative priority weighs of decision criteria in the same level, with respect to their upper criterions. Since the conventional eigenvector prioritization method is being doubt of its consistency, the Fuzzy prioritization method was used in this step to calculate the final priority weighs in the proposed model.

\subsection{Systemization of results}

The relative priority weigh of each criterion attained through previous steps was synthesized to obtain the final priority weigh. This process was computed by synthesizing all relative priority weighs of particular decision criteria from the bottom level to the top level. The outcome is a normalized vector of the overall weighs of the alternatives, which are then ranked in order. In response to the final ranking of each criterion, the users can take risk mitigation actions. Risk mitigation is a plan that reduces risk impact on the project performance. Options available for mitigation include "control", "avoidance", and "transfer". A mitigation plan could be carried out to reduce or to eliminate the risks with the selected higher priority weighs, with respect to the time, cost and quality of a project.

\section{Mechanism and appearance of the developed FSM}

Eventually, a Fuzzy Synthetic Model, abbreviated as FSM, was developed as shown in Figure 3. There are six steps within the model, which are delineated in the following sections.

Step 1: Establishment of Risk Assessment Team. In this step, the weighs were calculated to allocate difference contribution factors to the experts. If there 


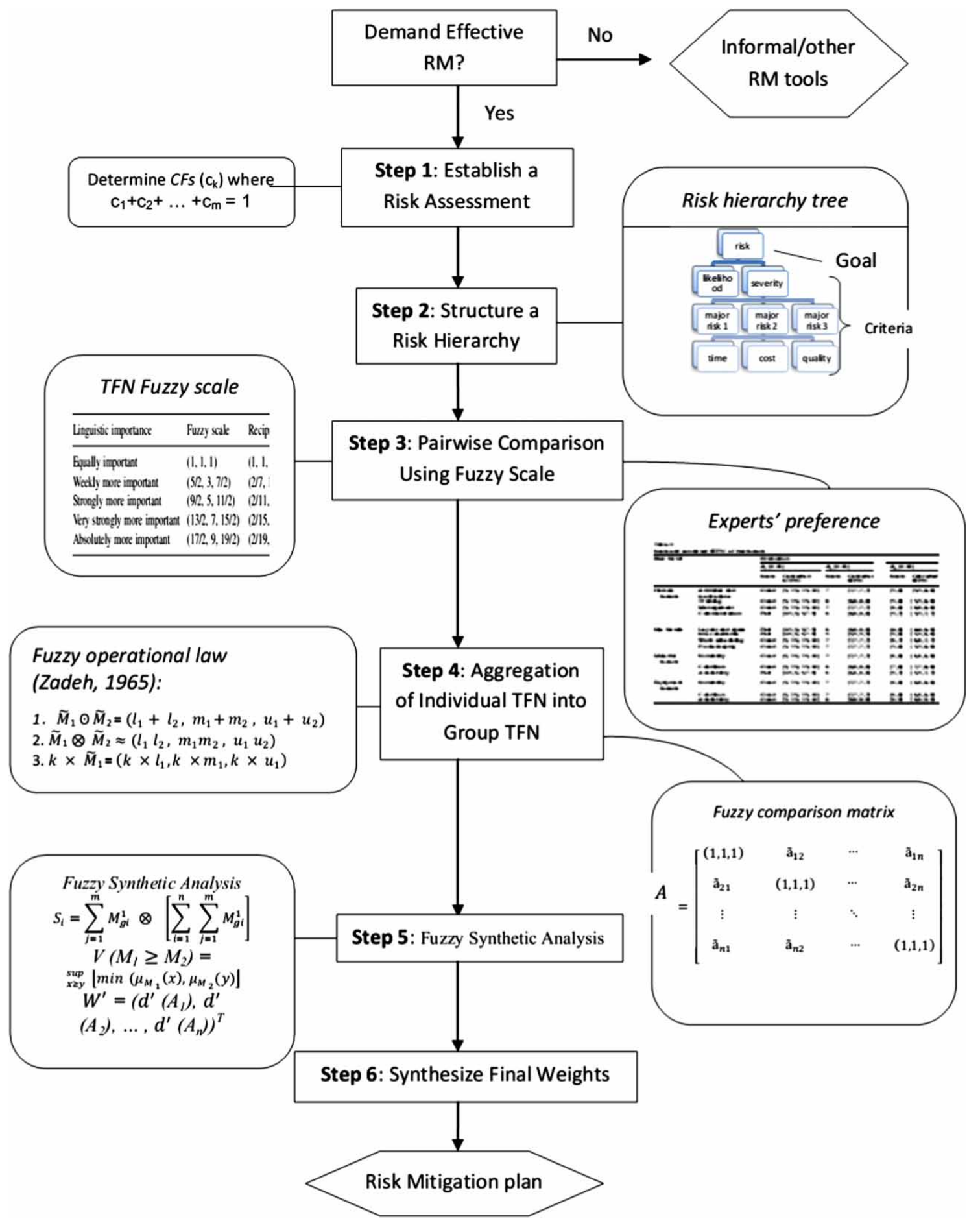

Fig. 3. The developed Fuzzy Synthetic Model (FSM)

are $m$ experts in the risk assessment team, the $k^{\text {th }}$ expert $E_{k}$ is allocated a contribution factor $c_{k}$ as defined in Eq. (1):

$$
c_{1}+c_{2}+\ldots+c_{m}, \quad \text { where } c_{k}[0,1] .
$$

Step 2: Structuring Risk Hierarchy Tree. The risk identification process was conducted based on the nature of a project. This is to anticipate potential risks on the stage of project development. The intuitive method was applied. The risks identified were structured into a simple hierarchy tree. The risks are grouped on the basis of their characteristics and the level of decomposition is non-limited. It depends on the variables to be measured in a project.

Step 3: Pairwise Comparison Using Fuzzy Comparison Scale. Pairwise comparison was carried out to determine the relative importance weighs of criteria. Every expert in the risk assessment team is required to 
compare those risks in a pairwise manner, via fuzzy scale, to produce a Fuzzy comparison matrix as shown in Eq. (2). TFN is used to convert the corresponding linguistic judgment according to the Fuzzy comparison scale:

$$
\tilde{A}=\left[\begin{array}{cccc}
(1,1,1) & \widetilde{\mathrm{a}}_{12} & \cdots & \widetilde{\mathrm{a}}_{1 n} \\
\widetilde{\mathrm{a}}_{21} & (1,1,1) & \cdots & \widetilde{\mathrm{a}}_{2 n} \\
\vdots & \vdots & \ddots & \vdots \\
\widetilde{\mathrm{a}}_{n 1} & \widetilde{\mathrm{a}}_{n 2} & \cdots & (1,1,1)
\end{array}\right],
$$

where $\tilde{A}$ represents a fuzzified reciprocal $n-n$ judgment matrix containing all pairwise comparison $\tilde{a}_{i j}$ between elements $i$ and $j$ for all $i, j=\{1,2, \ldots, n\}$; û and all $\tilde{a}_{i j}$ are triangular fuzzy numbers $\tilde{a}_{i j}=\left(l_{i j}, m_{i j}, u_{i j}\right)$ with $l_{i j}$ the lower and $u_{i j}$ the upper limit and $m_{i j}$ is the point where the membership function $\mu(x)=1$.

Step 4: Aggregation of Individual TFNs into Group TFN. The pairwise judgments of individual TFNs were aggregated into a group Fuzzy number using the operational laws base on Zadeh (1965), which are defined as:

- Fuzzy addition:

$$
\tilde{M}_{1} \oplus \tilde{M}_{2}=\left(l_{1}+l_{2}, m_{1}+m_{1}, u_{1}+u_{2}\right) ;
$$

- Fuzzy multiplication:

$$
\tilde{M}_{1} \odot \tilde{M}_{2} \approx\left(l_{1}+l_{2}, m_{1}+m_{1}, u_{1}+u_{2}\right) ;
$$

- The inverse of triangular fuzzy number $\left.\tilde{M}=l_{l}, m_{l}, u_{1}\right)$ :

$$
M_{1}^{-1} \approx\left(\frac{1}{u_{1}}, \frac{1}{m_{1}}, \frac{1}{l_{1}}\right)
$$

Table 4. Experts and their respective contribution factors in the model Pilot Run

\begin{tabular}{llcc}
\hline $\begin{array}{l}\text { Expert } \\
\left(E_{k}\right)\end{array}$ & \multicolumn{1}{c}{ Title } & $\begin{array}{c}\text { Working } \\
\text { experience } \\
\text { (Year) }\end{array}$ & $\begin{array}{c}\text { Contribution } \\
\text { Factor }\left(C_{k}\right)\end{array}$ \\
\hline$E_{1}$ & $\begin{array}{l}\text { Project } \\
\text { manager }\end{array}$ & 7 & 0.22 \\
$E_{2}$ & $\begin{array}{l}\text { Project } \\
\text { coordinator } \\
\text { Contractor } \\
\text { manager } \\
E_{3}\end{array}$ & 11 & 0.34 \\
$E_{4}$ & $\begin{array}{l}\text { Engineer in } \\
\text { Chief }\end{array}$ & 9 & 0.16 \\
Total & & $\mathbf{3 2}$ & 0.28 \\
\hline
\end{tabular}
number:

- The scalar multiplication of a triangular fuzzy

$$
\begin{aligned}
& k \times \tilde{M}_{1}=\left(k \times l_{1}, k \times m_{10}, k \times u_{1}\right) \text { if } k>0 ; \\
& k \times \tilde{M}_{1}=\left(k \times u_{1}, k \times m_{10}, k \times l_{1}\right) \text { if } k>0 .
\end{aligned}
$$

Step 5: Fuzzy Synthetic Analysis. Fuzzy synthetic analysis was carried out to calculate the relative priority weighs of criteria. According to Chang (1996), there are three procedures involved as described below:

Procedure 1: Calculate the Fuzzy Synthetic Extent Values:

$$
S_{i}=\sum_{j=i}^{m} M_{g i}^{1} \otimes\left[\sum_{j=i}^{m} M_{g i}^{1}\right] ;
$$

Procedure 2: Calculate the Degree of Possibility:

$$
V\left(M_{1} \geq M_{2}\right)=\sup _{x \geq y}\left[\min \left(\mu_{M_{1}}(x), \mu_{M_{2}}(y)\right)\right],
$$

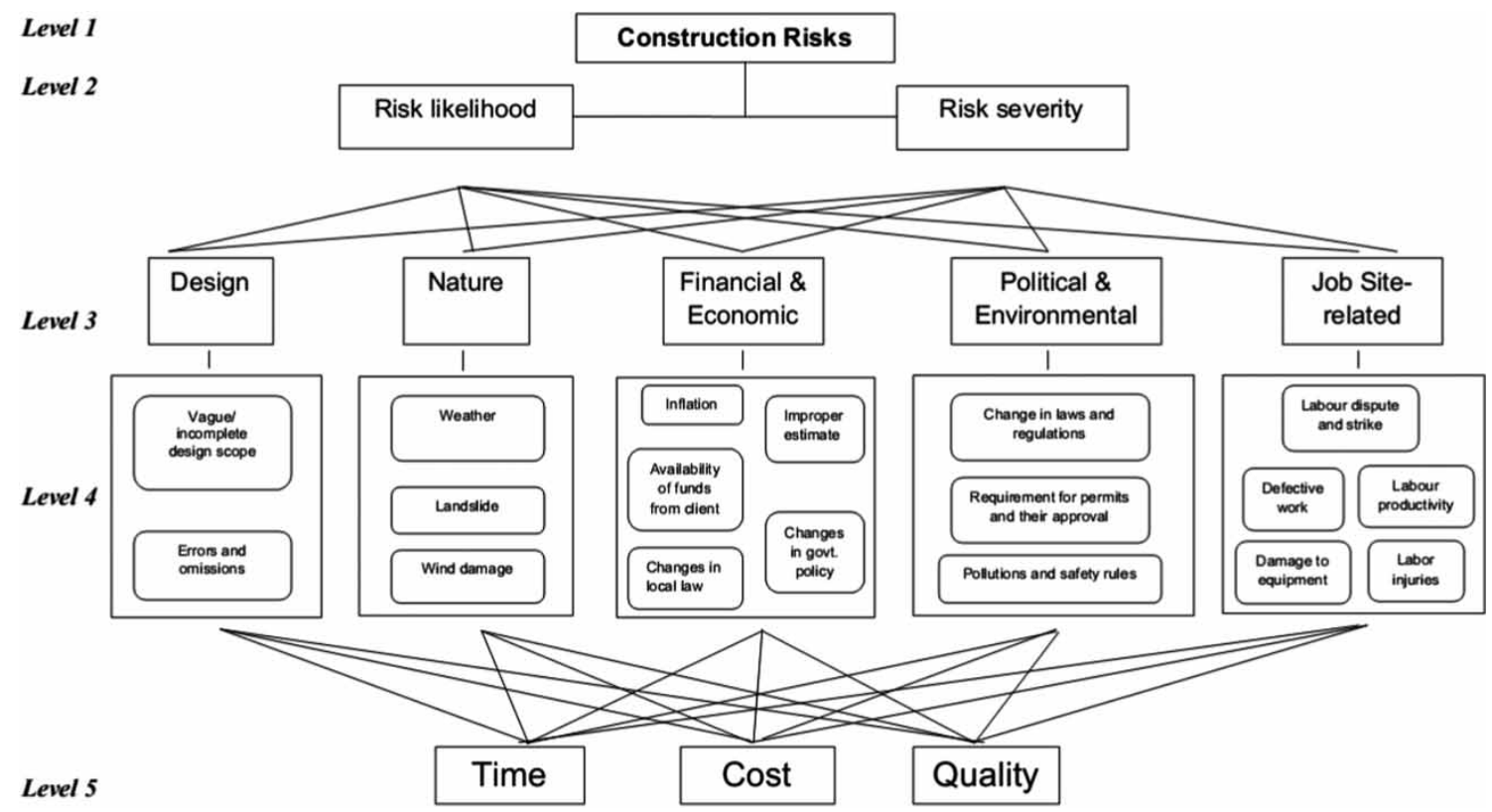

Fig. 4. Breakdown structure of construction project risks 
Table 5. Evaluation of sub-criteria with respect to "Weather" (Level 4)

\begin{tabular}{|c|c|c|c|c|c|c|c|c|}
\hline & & & \multicolumn{2}{|r|}{ Time } & \multicolumn{2}{|c|}{ Cost } & \multicolumn{2}{|c|}{ Quality } \\
\hline & & & Scale & Converted TFN & Scale & Converted TFN & Scale & Converted TFN \\
\hline \multirow[t]{5}{*}{ Time } & $E_{1}$ & 0.22 & & & $(2 / 7,1 / 3,2 / 5)$ & & $(2 / 11,1 / 5,2 / 9)$ & \\
\hline & $E_{2}$ & 0.34 & & & $(2 / 11,1 / 5,2 / 9)$ & & $(2 / 7,1 / 3,2 / 5)$ & \\
\hline & $E_{3}$ & 0.16 & & & $(2 / 7,1 / 3,2 / 5)$ & & $(2 / 11,1 / 5,2 / 9)$ & \\
\hline & $E_{4}$ & 0.28 & & & $(2 / 7,1 / 3,2 / 5)$ & & $(2 / 11,1 / 5,2 / 9)$ & \\
\hline & Aggregation & & & $(1.00,1.00,1.00)$ & & $(0.25,0.29,0.34)$ & & $(0.22,0.25,0.28)$ \\
\hline \multirow[t]{5}{*}{ Cost } & $E_{1}$ & 0.22 & $(5 / 2,3,7 / 2)$ & & & & $(2 / 7,1 / 3,2 / 5)$ & \\
\hline & $E_{2}$ & 0.34 & $(9 / 2,5,11 / 2)$ & & & & $(2 / 7,1 / 3,2 / 5)$ & \\
\hline & $E_{3}$ & 0.16 & $(5 / 2,3,7 / 2)$ & & & & $(2 / 7,1 / 3,2 / 5)$ & \\
\hline & $E_{4}$ & 0.28 & $(5 / 2,3,7 / 2)$ & & & & $(2 / 11,1 / 5,2 / 9)$ & \\
\hline & Aggregation & & & $(3.18,3.68,4.18)$ & & $(1.00,1.00,1.00)$ & & $(0.26,0.30,0.35)$ \\
\hline \multirow[t]{5}{*}{ Quality } & $E_{1}$ & 0.22 & $(9 / 2,5,11 / 2)$ & & $(5 / 2,3,7 / 2)$ & & & \\
\hline & $E_{2}$ & 0.34 & $(5 / 2,3,7 / 2)$ & & $(5 / 2,3,7 / 2)$ & & & \\
\hline & $E_{3}$ & 0.16 & $(9 / 2,5,11 / 2)$ & & $(5 / 2,3,7 / 2)$ & & & \\
\hline & $E_{4}$ & 0.28 & $(9 / 2,5,11 / 2)$ & & $(9 / 2,5,11 / 2)$ & & & \\
\hline & Aggregation & & & $(3.82,4.32,4.82)$ & & $(3.06,3.56,4.06)$ & & $(1.00,1.00,1.00)$ \\
\hline
\end{tabular}

where: $V\left(M_{1} \geq M_{2}\right)=1$ if $m_{1} \geq m_{2}$

$$
\begin{gathered}
V\left(M_{1} \geq M_{2}\right)=\operatorname{hgt}\left(M_{1} \cap M_{2}\right)=\mu_{M_{1}}(d) ; \quad \\
V\left(M_{1} \geq M_{2}\right)=\operatorname{hgt}\left(M_{1} \cap M_{2}\right) \frac{l_{1}-u_{2}}{\left(m_{2}-u_{2}\right)-\left(m_{1}-l_{1}\right)}
\end{gathered}
$$
Vectors:

Procedure 3: Calculate the Normalized Weigh

$$
\begin{aligned}
& V\left(M \geq M_{1}, M_{2}, \ldots, M_{k}\right) \\
& \quad=V\left[\left(M \geq M_{1}\right) \text { and }\left(M \geq M_{2}\right) \text { and }\left(M \geq M_{k}\right)\right] \\
& \quad=\min V\left(M \geq M_{i}\right), i=1,2,3, \ldots, k .
\end{aligned}
$$

Assuming that:

$$
d^{\prime}\left(A_{i}\right)=\min V\left(S_{i} \geq S_{k}\right)
$$

for $k=1,2, \ldots, n ; k \neq i$. Then the weigh vector is given by Eq. (14):

$$
W^{\prime}=\left(d^{\prime}\left(A_{1}\right), d^{\prime}\left(A_{2}\right), \ldots, d^{\prime}\left(A_{n}\right)\right)^{T},
$$

where: $A_{1}(i=1,2, \ldots, n)$ are $n$ elements.

Via normalization of $\mathrm{W}^{\prime}$, the normalized weigh vectors are as Eq. (15):

$$
W=\left(d\left(A_{1}\right), d\left(A_{2}\right), \ldots, d\left(A_{n}\right)\right)^{T},
$$

where $W$ is a non-fuzzy number.

Table 6. Fuzzy comparison matrix with respect to "Weather" (Level 4)

\begin{tabular}{llll}
\hline & Time & Cost & Quality \\
\hline Time & $(1.00,1.00,1.00)$ & $(0.25,0.29,0.34)$ & $(0.22,0.25,0.28)$ \\
Cost & $(3.18,3.68,4.18)$ & $(1.00,1.00,1.00)$ & $(0.26,0.30,0.35)$ \\
Quality & $(3.82,4.32,4.82)$ & $(3.06,3.56,4.06)$ & $(1.00,1.00,1.00)$ \\
\hline
\end{tabular}

Step 6: Synthesizing Final Weighs. Finally, the relative priority weighs of the criteria were synthesized across the hierarchy tree to produce final weighs with respect to project objectives. Consequently, risk controlling process could take place to mitigate and monitor the highest risky uncertainty.

\section{Pilot Run and validation of FSM}

The Pilot Run project for the developed FSM was conducted with a G7 contractor who managed to assess the potential risks in a ten-floor high-rise building project at Kepong, Kuala Lumpur. The goal is to take into account all the possible impact of risks towards the project objectives. The Pilot Run project is presented here to validate the implementation of the developed FSM.

\subsection{Pilot Run: established risk assessment team}

Four experts in the G7 contractor were selected to form a risk assessment team. The profiles of these 4 experts are presented in Table 4. Prior to the risk analysis process, the contribution factor for the first expert $c_{1}$ was calculated based on his working experience related to the risk assessment on this type of construction, so that his weighing was determined by Eq. (16). Similarly, the contribution factors for other experts were calculated as shown in Table 4:

$$
C_{1} \text { for } E_{1}=\frac{7}{7+11+5+9}=0.22 \text {. }
$$

\subsection{Pilot Run: structured hierarchy tree}

The hierarchy tree was structured as shown in Figure 4. The top level is the overall goal of the risk assessment problem defined as "Construction Risks" 
Table 7. (Level 4) Matrices of pairwise comparisons and respective normalized weigh vectors

\begin{tabular}{|c|c|c|c|c|c|c|c|}
\hline \multicolumn{4}{|c|}{ Vague/incomplete Design Scope: WVDS $=(0.34,0.66,0) \mathrm{T}$} & \multicolumn{4}{|c|}{ Errors and Omissions: $\mathrm{WEO}=(0.20,0.62,0.18) \mathrm{T}$} \\
\hline & Time & Cost & Quality & & Time & Cost & Quality \\
\hline Time & $(1.00,1.00,1.00)$ & $(0.25,0.29,0.34)$ & $(0.22,0.25,0.28)$ & Time & $(1.00,1.00,1.00)$ & $(0.07,0.12,0.18)$ & $(0.09,0.15,0.18)$ \\
\hline Cost & $(3.18,3.68,4.18)$ & $(1.00,1.00,1.00)$ & $(0.26,0.30,0.35)$ & Cost & $(4.06,4.56,5.06)$ & $(1.00,1.00,1.00)$ & $(0.12,0.17,0.21)$ \\
\hline Quality & $(3.82,4.32,4.82)$ & $(3.06,3.56,4.06)$ & $(1.00,1.00,1.00)$ & Quality & $(5.82,6.32,6.82)$ & $(4.13,4.56,5.06)$ & $(1.00,1.00,1.00)$ \\
\hline \multicolumn{4}{|c|}{ Landslide: $\mathrm{WL}=(0.13,0.48,0.39) \mathrm{T}$} & \multicolumn{4}{|c|}{ Wind Damage: WWD $=(0,1,0) \mathrm{T}$} \\
\hline & Time & Cost & Quality & & Time & Cost & Quality \\
\hline Time & $(1.00,1.00,1.00)$ & $(0.25,0.29,0.34)$ & $(0.22,0.25,0.28)$ & Time & $(1.00,1.00,1.00)$ & $(0.31,0.39,0.44)$ & $(0.32,0.39,0.48)$ \\
\hline Cost & $(3.18,3.68,4.18)$ & $(1.00,1.00,1.00)$ & $(0.26,0.30,0.35)$ & Cost & $(3.94,4.11,4.68)$ & $(1.00,1.00,1.00)$ & $(0.30,0.33,0.36)$ \\
\hline Quality & $(3.20,3.45,4.12)$ & $(3.06,3.28,4.18)$ & $(1.00,1.00,1.00)$ & Quality & $(3.82,4.32,4.82)$ & $(4.09,4.56,5.06)$ & $(1.00,1.00,1.00)$ \\
\hline \multicolumn{4}{|c|}{ Inflation: $\mathrm{WI}=(0,0.40,0.60) \mathrm{T}$} & \multicolumn{4}{|c|}{ Availability of Funds from Client: WAFC $=(0.05,0.58,0.37) \mathrm{T}$} \\
\hline & Time & Cost & Quality & & Time & Cost & Quality \\
\hline Time & $(1.00,1.00,1.00)$ & $(0.25,0.31,0.34)$ & $(0.36,0.41,0.43)$ & Time & $(1.00,1.00,1.00)$ & $(0.26,0.30,0.35)$ & $(0.09,0.15,0.18)$ \\
\hline Cost & $(3.18,3.68,4.18)$ & $(1.00,1.00,1.00)$ & $(0.28,0.30,0.38)$ & Cost & $(4.06,4.56,5.06)$ & $(1.00,1.00,1.00)$ & $(0.20,0.25,0.30)$ \\
\hline Quality & $(3.82,4.32,4.82)$ & $(3.06,3.56,4.06)$ & $(1.00,1.00,1.00)$ & Quality & $(5.82,6.32,6.82)$ & $(4.13,4.56,5.06)$ & $(1.00,1.00,1.00)$ \\
\hline \multicolumn{4}{|c|}{ Changes in Local Law: WCLL $=(0,1,0) \mathrm{T}$} & \multicolumn{4}{|c|}{ Changes in Government Policy: WCGP $=(1,0,0) \mathrm{T}$} \\
\hline & Time & Cost & Quality & & Time & Cost & Quality \\
\hline Time & $(1.00,1.00,1.00)$ & $(0.27,0.31,0.34)$ & $(0.19,0.21,0.25)$ & Time & $(1.00,1.00,1.00)$ & $(0.06,0.10,0.17)$ & $(0.06,0.15,0.18)$ \\
\hline Cost & $(3.20,3.45,4.12)$ & $(1.00,1.00,1.00)$ & $(0.17,0.18,0.24)$ & Cost & $(5.82,6.32,6.82)$ & $(1.00,1.00,1.00)$ & $(0.11,0.16,0.20)$ \\
\hline Quality & $(3.51,4.32,4.94)$ & $(3.06,3.56,4.06)$ & $(1.00,1.00,1.00)$ & Quality & $(6.45,7.16,7.83)$ & $(5.15,5.36,6.24)$ & $(1.00,1.00,1.00)$ \\
\hline \multicolumn{4}{|c|}{ Improper Estimate: $\mathrm{WIE}=(0.03,0.81,0.06) \mathrm{T}$} & \multicolumn{4}{|c|}{ Changes in Laws and Regulations: WCLR $=(0.46,0.54,0) \mathrm{T}$} \\
\hline & Time & Cost & Quality & & Time & Cost & Quality \\
\hline Time & $(1.00,1.00,1.00)$ & $(0.26,0.30,0.35)$ & $(0.09,0.15,0.18)$ & Time & $(1.00,1.00,1.00)$ & $(0.31,0.39,0.44)$ & $(0.32,0.39,0.48)$ \\
\hline Cost & $(4.06,4.56,5.06)$ & $(1.00,1.00,1.00)$ & $(0.20,0.25,0.30)$ & Cost & $(3.18,3.68,4.18)$ & $(1.00,1.00,1.00)$ & $(0.28,0.30,0.38)$ \\
\hline Quality & $(5.82,6.32,6.82)$ & $(4.13,4.56,5.06)$ & $(1.00,1.00,1.00)$ & Quality & $(3.51,4.32,4.94)$ & $(3.20,3.45,4.12)$ & $(1.00,1.00,1.00)$ \\
\hline \multicolumn{4}{|c|}{ Requirement Permits \& Approval: WRPA $=(0.03,0.73,0.24) \mathrm{T}$} & \multicolumn{4}{|c|}{ Pollutions and Safety Rules: WPSR $=(0,0.97,0.03) \mathrm{T}$} \\
\hline
\end{tabular}


Table 7 (Continued)

\begin{tabular}{|c|c|c|c|c|c|c|c|}
\hline \multicolumn{4}{|c|}{ Vague/incomplete Design Scope: WVDS $=(0.34,0.66,0) \mathrm{T}$} & \multicolumn{4}{|c|}{ Errors and Omissions: $\mathrm{WEO}=(0.20,0.62,0.18) \mathrm{T}$} \\
\hline & Time & Cost & Quality & & Time & Cost & Quality \\
\hline & Time & Cost & Quality & & Time & Cost & Quality \\
\hline Time & $(1.00,1.00,1.00)$ & $(0.25,0.29,0.34)$ & $(0.22,0.25,0.28)$ & Time & $(1.00,1.00,1.00)$ & $(0.06,0.10,0.17)$ & $(0.06,0.15,0.18)$ \\
\hline Cost & $(3.18,3.68,4.18)$ & $(1.00,1.00,1.00)$ & $(0.26,0.30,0.35)$ & Cost & $(4.06,4.56,5.06)$ & $(1.00,1.00,1.00)$ & $(0.11,0.16,0.20)$ \\
\hline Quality & $(3.51,4.32,4.94)$ & $(3.20,3.45,4.12)$ & $(1.00,1.00,1.00)$ & Quality & $(5.82,6.32,6.82)$ & $(4.13,4.56,5.06)$ & $(1.00,1.00,1.00)$ \\
\hline \multicolumn{4}{|c|}{ Labor Dispute and Strike: WLDS $=(0,0.40,0.60) \mathrm{T}$} & \multicolumn{4}{|c|}{ Defective Work: WDW $=(0.05,0.95,0) \mathrm{T}$} \\
\hline & Time & Cost & Quality & & Time & Cost & Quality \\
\hline Time & $(1.00,1.00,1.00)$ & $(0.31,0.39,0.44)$ & $(0.32,0.39,0.48)$ & Time & $(1.00,1.00,1.00)$ & $(0.04,0.09,0.15)$ & $(0.10,0.11,0.17)$ \\
\hline Cost & $(3.18,3.68,4.18)$ & $(1.00,1.00,1.00)$ & $(0.30,0.33,0.36)$ & Cost & $(7.44,7.56,8.06)$ & $(1.00,1.00,1.00)$ & $(0.20,0.25,0.30)$ \\
\hline Quality & $(4.13,4.56,5.06)$ & $(4.35,4.56,5.06)$ & $(1.00,1.00,1.00)$ & Quality & $(8.12,8.32,8.94)$ & $(7.46,7.85,8.02)$ & $(1.00,1.00,1.00)$ \\
\hline \multicolumn{4}{|c|}{ Damage to Equipment: $\mathrm{WDE}=(0,1,0) \mathrm{T}$} & \multicolumn{4}{|c|}{ Labor Productivity: $\mathrm{WLP}=(0,0,1) \mathrm{T}$} \\
\hline & Time & Cost & Quality & & Time & Cost & Quality \\
\hline Time & $(1.00,1.00,1.00)$ & $(0.25,0.29,0.34)$ & $(0.22,0.25,0.28)$ & Time & $(1.00,1.00,1.00)$ & $(0.25,0.29,0.34)$ & $(0.22,0.25,0.28)$ \\
\hline Cost & $(5.54,5.64,6.18)$ & $(1.00,1.00,1.00)$ & $(0.26,0.30,0.35)$ & Cost & $(3.18,3.68,4.18)$ & $(1.00,1.00,1.00)$ & $(0.26,0.30,0.35)$ \\
\hline Quality & $(4.82,5.32,5.82)$ & $(6.06,6.56,7.06)$ & $(1.00,1.00,1.00)$ & Quality & $(3.51,4.32,4.94)$ & $(3.20,3.45,4.12)$ & $(1.00,1.00,1.00)$ \\
\hline \multicolumn{8}{|c|}{ Labor Injuries: $\mathrm{WLI}=(0.46,0.54,0) \mathrm{T}$} \\
\hline & Time & Cost & Quality & & & & \\
\hline Time & $(1.00,1.00,1.00)$ & $(0.04,0.09,0.15)$ & $(0.08,0.11,0.13)$ & & & & \\
\hline Cost & $(7.44,7.56,8.06)$ & $(1.00,1.00,1.00)$ & $(0.20,0.25,0.30)$ & & & & \\
\hline Quality & $(8.23,8.32,9.94)$ & $(7.20,7.45,8.12)$ & $(1.00,1.00,1.00)$ & & & & \\
\hline
\end{tabular}


Table 8. (Level 3) Matrices of pairwise comparisons and respective normalized weigh vectors

\begin{tabular}{|c|c|c|c|c|c|c|c|c|c|}
\hline \multicolumn{3}{|c|}{ Design: $\mathrm{W}_{\mathrm{D}}=(0.67,0.33)^{\mathrm{T}}$} & & \multicolumn{4}{|c|}{ Nature: $\mathrm{W}_{\mathrm{N}}=(0.63,0.15,0.22)^{\mathrm{T}}$} & & \\
\hline & $\begin{array}{l}\text { Vague/incomplete } \\
\text { Design scope }\end{array}$ & $\begin{array}{l}\text { Errors and } \\
\text { omissions }\end{array}$ & & & Weather & Landslide & Wind damage & & \\
\hline $\begin{array}{l}\text { Vague/ } \\
\text { incomplete } \\
\text { Design } \\
\text { scope }\end{array}$ & $(1.00,1.00,1.00)$ & $(5.06,5.54,6.13)$ & & $\begin{array}{l}\text { Weather } \\
\text { Landslide } \\
\text { Wind } \\
\text { damage }\end{array}$ & $\begin{array}{l}(1.00,1.00,1.00) \\
(4.18,4.68,5.18) \\
(3.82,4.32,4.82)\end{array}$ & $\begin{array}{l}(1.00,1.00,1.00) \\
(3.06,3.56,4.06)\end{array}$ & $\begin{array}{l}(0.26,0.30,0.35) \\
(1.00,1.00,1.00)\end{array}$ & & \\
\hline \multicolumn{4}{|c|}{ Political and Environmental: $\mathrm{W}_{\mathrm{PE}}=(0.43,0.37,0.20)^{\mathrm{T}}$} & \multicolumn{6}{|c|}{ Financial and Economic: $\mathrm{W}_{\mathrm{FE}}=(0.19,0.04,0.15,0.05,0.57)^{\mathrm{T}}$} \\
\hline & $\begin{array}{l}\text { Change in laws } \\
\text { and regulations }\end{array}$ & $\begin{array}{l}\text { Requirement for } \\
\text { permits and their } \\
\text { approval }\end{array}$ & $\begin{array}{l}\text { Pollutions and } \\
\text { safety rules }\end{array}$ & & Inflation & $\begin{array}{l}\text { Availability of } \\
\text { funds from client }\end{array}$ & $\begin{array}{l}\text { Changes in local } \\
\text { law }\end{array}$ & $\begin{array}{l}\text { Changes in } \\
\text { govt. policy }\end{array}$ & Improper estimate \\
\hline $\begin{array}{l}\text { Change in } \\
\text { laws and } \\
\text { regulations }\end{array}$ & $1.00,1.00,1.00$ & $0.13,0.16,0.22$ & $0.25,0.27,0.35$ & Inflation & $1.00,1.00,1.00$ & $0.16,0.21,0.25$ & $0.18,0.20,0.27$ & $0.17,0.21,0.28$ & $0.22,0.27,0.33$ \\
\hline $\begin{array}{l}\text { Requirement } \\
\text { for permits } \\
\text { and their } \\
\text { approval }\end{array}$ & $3.24,3.78,4.26$ & $1.00,1.00,1.00$ & $0.26,0.33,0.37$ & $\begin{array}{l}\text { Availability } \\
\text { of funds } \\
\text { from client }\end{array}$ & $5.03,5.25,6.26$ & $1.00,1.00,1.00$ & $0.26,0.31,0.32$ & $0.10,0.15,0.22$ & $0.13,0.15,0.18$ \\
\hline \multirow[t]{10}{*}{$\begin{array}{l}\text { Pollutions and } \\
\text { safety rules }\end{array}$} & $3.89,4.22,4.78$ & $3.22,3.75,4.18$ & $1.00,1.00,1.00$ & $\begin{array}{l}\text { Changes in } \\
\text { local law }\end{array}$ & $5.15,5.36,6.24$ & $6.32,6.46,6.88$ & $1.00,1.00,1.00$ & $0.19,0.22,0.23$ & $0.21,0.33,0.35$ \\
\hline & & & & $\begin{array}{l}\text { Changes in } \\
\text { govt. policy }\end{array}$ & $6.45,7.16,7.83$ & $6.22,6.46,6.84$ & $5.17,5.56,6.67$ & $1.00,1.00,1.00$ & $0.19,0.26,0.30$ \\
\hline & & & & $\begin{array}{l}\text { Improper } \\
\text { estimate }\end{array}$ & $6.64,7.25,7.46$ & $6.45,7.16,7.83$ & $5.82,6.32,6.82$ & $5.15,5.36,6.24$ & $1.00,1.00,1.00$ \\
\hline & & & & \multicolumn{6}{|c|}{ Job Site-related: $\mathrm{W}_{\mathrm{JS}}=(0.20,0.08,0.11,0.07,0.64)^{\mathrm{T}}$} \\
\hline & & & & & $\begin{array}{l}\text { Labour dispute } \\
\text { and strike }\end{array}$ & Defective work & $\begin{array}{l}\text { Damage to } \\
\text { equipment }\end{array}$ & $\begin{array}{l}\text { Labour } \\
\text { productivity }\end{array}$ & Labour injuries \\
\hline & & & & $\begin{array}{l}\text { Labour } \\
\text { dispute and } \\
\text { strike }\end{array}$ & $1.00,1.00,1.00$ & $0.16,0.21,0.25$ & $0.18,0.20,0.27$ & $0.17,0.21,0.28$ & $0.22,0.27,0.33$ \\
\hline & & & & $\begin{array}{l}\text { Defective } \\
\text { work }\end{array}$ & $5.03,5.25,6.26$ & $1.00,1.00,1.00$ & $0.26,0.31,0.32$ & $0.10,0.15,0.22$ & $0.13,0.15,0.18$ \\
\hline & & & & $\begin{array}{l}\text { Damage to } \\
\text { equipment }\end{array}$ & $5.15,5.36,6.24$ & $6.32,6.46,6.88$ & $1.00,1.00,1.00$ & $0.19,0.22,0.23$ & $0.21,0.33,0.35$ \\
\hline & & & & $\begin{array}{l}\text { Labour } \\
\text { productivity }\end{array}$ & $6.45,7.16,7.83$ & $6.22,6.46,6.84$ & $5.17,5.56,6.67$ & $1.00,1.00,1.00$ & $0.19,0.26,0.30$ \\
\hline & & & & $\begin{array}{l}\text { Labour } \\
\text { injuries }\end{array}$ & $6.64,7.25,7.46$ & $6.45,7.16,7.83$ & $5.82,6.32,6.82$ & $5.15,5.36,6.24$ & $1.00,1.00,1.00$ \\
\hline
\end{tabular}


Table 9. (Level 2) Matrices of pairwise comparisons and respective normalized weigh vectors

\begin{tabular}{|c|c|c|c|c|c|}
\hline \multicolumn{6}{|c|}{ Risk Likelihood: $\mathrm{W}_{\mathrm{RL}}=(0.42,0.29,0.10,0.07,0.12)^{\mathrm{T}}$} \\
\hline & Design & Nature & $\begin{array}{l}\text { Financial and } \\
\text { economic }\end{array}$ & $\begin{array}{l}\text { Political and } \\
\text { environmental }\end{array}$ & Job site-related \\
\hline Design & $(1.00,1.00,1.00)$ & $(0.35,0.41,0.44)$ & $(0.37,0.40,0.46)$ & $(0.31,0.38,0.44)$ & $(0.30,0.37,0.42)$ \\
\hline Nature & $(5.15,5.36,6.24)$ & $(1.00,1.00,1.00)$ & $(0.26,0.31,0.32)$ & $(0.30,0.33,0.40)$ & $(0.33,0.35,0.38)$ \\
\hline Financial and economic & $(5.17,5.56,6.67)$ & $(5.03,5.25,6.26)$ & $(1.00,1.00,1.00)$ & $(0.29,0.33,0.38)$ & $(0.31,0.33,0.38)$ \\
\hline Political \& environmental & $(5.22,5.12,5.82)$ & $(6.22,6.46,6.84)$ & $(5.15,5.36,6.24)$ & $(1.00,1.00,1.00)$ & $(0.29,0.36,0.38)$ \\
\hline Job site-related & $(5.12,5.33,6.77)$ & $(6.45,7.16,7.83)$ & $(5.82,6.32,6.82)$ & $(5.11,5.24,6.26)$ & $(1.00,1.00,1.00)$ \\
\hline \multicolumn{6}{|c|}{ Risk Severity: $\mathrm{W}_{\mathrm{RS}}=(0.21,0.19,0.10,0.05,0.45)^{\mathrm{T}}$} \\
\hline & Design & Nature & $\begin{array}{l}\text { Financial and } \\
\text { economic }\end{array}$ & $\begin{array}{l}\text { Political and } \\
\text { environmental }\end{array}$ & Job site-related \\
\hline Design & $(1.00,1.00,1.00)$ & $(0.16,0.21,0.25)$ & $(0.04,0.10,0.14)$ & $(0.17,0.21,0.28)$ & $(0.22,0.27,0.33)$ \\
\hline Nature & $(5.03,5.25,6.26)$ & $(1.00,1.00,1.00)$ & $(0.06,0.12,0.16)$ & $(0.10,0.15,0.22)$ & $(0.13,0.15,0.18)$ \\
\hline Financial and economic & $(5.11,5.24,6.26)$ & $(6.32,6.46,6.88)$ & $(1.00,1.00,1.00)$ & $(0.17,0.22,0.22)$ & $(0.21,0.26,0.29)$ \\
\hline Political \& environmental & $(6.45,7.16,7.83)$ & $(6.22,6.46,6.84)$ & $(5.17,5.56,6.67)$ & $(1.00,1.00,1.00)$ & $(0.19,0.26,0.30)$ \\
\hline Job site-related & $(6.64,7.25,7.46)$ & $(6.66,7.34,7.78)$ & $(5.22,5.12,5.82)$ & $(5.15,5.36,6.24)$ & $(1.00,1.00,1.00)$ \\
\hline
\end{tabular}

followed by two risk parameters, namely: risk likelihood and risk severity that located at the second level. The third and fourth levels are where all the identified risks situated. The lowest level presents the project objectives including time, cost, and quality. In this Pilot Run project, the risk assessment team identified five critical risk factors: Design, Nature, Financial \& Economic, Political \& Environment, and Job site-related. Under these five main factors, there are eighteen sub-factors as listed in Figure 4.

\subsection{Pilot Run: pairwise comparison using fuzzy scale}

In this step, pairwise comparison for every criterion was conducted at all these 5 levels in the hierarchy structure. Triangular fuzzy numbers (TFNs) in the pairwise comparison scale were used to determine the priorities of different criteria. Table 5 demonstrates the pairwise comparison results on determining the relative importance weighs for criteria with respect to "Weather" at level 4.

\subsection{Pilot Run: aggregation of individual TFNs into group TFN}

In this step, the contribution factor of each expert was multiplied with the corresponding individual TFNs.

Table 10. (Level 1) Matrices of pairwise comparisons and respective normalized weigh vectors

\begin{tabular}{lcc}
\hline \multicolumn{3}{c}{ Construction Risks: $W_{\mathrm{N}}=(0.57,0.43)^{\mathrm{T}}$} \\
\hline & Risk likelihood & Risk severity \\
\hline Risk likelihood & $(1.00,1.00,1.00)$ & $(0.16,0.29,0.31)$ \\
Risk severity & $(4.18,4.68,5.18)$ & $(1.00,1.00,1.00)$ \\
\hline
\end{tabular}

All the individual TFNs were aggregated into the group TFN. The aggregation score of each criterion was calculated using Eqs (3), (4), and (6). For instance, the aggregation score of "Cost and Time" under "Weather" was calculated as $(3.18,3.68,4.18)$ as shown in Eq. (17). The aggregated scores for other criteria were obtained in the same way. Once the aggregation process was completed, the fuzzy comparison matrix of the criteria was produced as shown in Table 6:

$$
\begin{aligned}
S_{\text {cost \& time }}^{*} & (5 / 2,3,7 / 2) \otimes 0.22 \otimes(9 / 2,5,11 / 2) \\
& \otimes 0.34 \oplus(5 / 2,3,7 / 2) \otimes 0.16 \\
& \oplus(5 / 2,3,7 / 2) \otimes 0.28 \\
= & (3.18,3.68,4.18) .
\end{aligned}
$$

\subsection{Pilot Run: calculated priority weighs using FSA}

The priority weighs of the criteria were computed using FSA. From Table 6, the value of fuzzy synthetic extent with respect to each criterion was calculated using Eq. (8). The results are:

$$
\begin{aligned}
S_{\text {Time }} & =(1.47,1.54,1.62) \otimes \frac{1}{17.03}+\frac{1}{15.04}+\frac{1}{17.93} \\
& =(0.09,0.10,0.12) ; \\
S_{\text {Cost }} & =(4.44,4.98,5.53) \otimes \frac{1}{17.03}+\frac{1}{15.04}+\frac{1}{17.93} \\
& =(0.26,0.32,0.40) ; \\
S_{\text {Quality }} & =(7.88,8.88,9.98) \otimes \frac{1}{17.03}+\frac{1}{15.04}+\frac{1}{17.39} \\
& =(0.46,0.58,0.72) .
\end{aligned}
$$


Table 11. Combination of priority weighs

Sub-criteria: Design

\begin{tabular}{|c|c|c|c|c|c|c|}
\hline & $\begin{array}{l}\text { Vague/incompleteDesign } \\
\text { scope }\end{array}$ & Errors and omissions & Alternative priority weigh & & & \\
\hline Weigh & 0.67 & 0.33 & & & & \\
\hline Time & 0.34 & 0.20 & 0.30 & & & \\
\hline Cost & 0.66 & 0.62 & 0.64 & & & \\
\hline Quality & 0 & 0.18 & 0.06 & & & \\
\hline \multicolumn{7}{|c|}{ Sub-criteria: Nature } \\
\hline & Weather & Landslide & Wind damage & Alternative priority weigh & & \\
\hline Weigh & 0.63 & 0.15 & 0.22 & & & \\
\hline Time & 0 & 0.13 & 0 & 0.10 & & \\
\hline Cost & 0.50 & 0.48 & 1 & 0.53 & & \\
\hline Quality & 0.50 & 0.39 & 0 & 0.37 & & \\
\hline \multicolumn{7}{|c|}{ Sub-criteria: Financial and Economic } \\
\hline & & & & & Improper estimate & \\
\hline & Inflation & Available of fund from client & Changes in local law & Changes in govt. policy & & Alternative priority weigh \\
\hline Weigh & 0.19 & 0.04 & 0.15 & 0.05 & 0.57 & \\
\hline Time & 0 & 0.05 & 0 & 1 & 0.03 & 0.07 \\
\hline Cost & 0.40 & 0.58 & 1 & 0 & 0.81 & 0.71 \\
\hline Quality & 0.60 & 0.37 & 0 & 0 & 0.16 & 0.22 \\
\hline \multicolumn{7}{|c|}{ Sub-criteria: Political and Environmental } \\
\hline & $\begin{array}{l}\text { Changes in laws and } \\
\text { regulations }\end{array}$ & $\begin{array}{l}\text { Requirement for permits and } \\
\text { their } \\
\quad \text { approval }\end{array}$ & Pollutions and safety rules & Alternative priority weigh & & \\
\hline Weigh & 0.43 & 0.37 & 0.20 & & & \\
\hline Time & 0.46 & 0.03 & 0 & 0.21 & & \\
\hline Cost & 0.54 & 0.73 & 0.97 & 0.69 & & \\
\hline
\end{tabular}


Sub-criteria: Design

\begin{tabular}{|c|c|c|c|c|c|c|}
\hline \multicolumn{4}{|c|}{ Sub-criteria: Design } & & & \\
\hline \multicolumn{2}{|r|}{$\begin{array}{l}\text { Vague/incompleteDesign } \\
\text { scope }\end{array}$} & \multirow{2}{*}{$\begin{array}{c}\text { Errors and omissions } \\
0.24\end{array}$} & Alternative priority weigh & & & \\
\hline Quality & 0 & & 0.03 & 0.10 & & \\
\hline \multicolumn{7}{|c|}{ Sub-criteria: Job Site-related } \\
\hline & Labour dispute and strike & Defective work & Damage to equipment & Labour productivity & Labour injuries & Alternative priority weigh \\
\hline Weigh & 0.20 & 0.08 & 0.11 & 0.07 & 0.64 & \\
\hline Time & 0 & 0.05 & 0 & 0 & 0.46 & 0.30 \\
\hline Cost & 0.40 & 0.95 & 1 & 0 & 0.54 & 0.51 \\
\hline Quality & 0.60 & 0 & 0 & 1 & 0 & 0.19 \\
\hline \multicolumn{7}{|c|}{ Sub-criteria: Risk Likelihood } \\
\hline & Design & Nature & Financial and economic & Political and environmental & Job site-related & Alternative priority weigh \\
\hline Weigh & 0.42 & 0.29 & 0.10 & 0.07 & 0.12 & \\
\hline Time & 0.30 & 0.10 & 0.07 & 0.21 & 0.30 & 0.21 \\
\hline Cost & 0.64 & 0.53 & 0.71 & 0.69 & 0.51 & 0.61 \\
\hline Quality & 0.06 & 0.37 & 0.22 & 0.10 & 0.19 & 0.18 \\
\hline \multicolumn{7}{|c|}{ Sub-criteria: Risk Severity } \\
\hline & Design & Nature & Financial and economic & Political and environmental & Job site-related & Alternative priority weigh \\
\hline Weigh & 0.21 & 0.19 & 0.10 & 0.05 & 0.45 & \\
\hline Time & 0.30 & 0.10 & 0.07 & 0.21 & 0.30 & 0.23 \\
\hline Cost & 0.64 & 0.53 & 0.71 & 0.69 & 0.51 & 0.58 \\
\hline Quality & 0.06 & 0.37 & 0.22 & 0.10 & 0.19 & 0.19 \\
\hline \multicolumn{4}{|c|}{ Main criteria: Construction risks } & & & \\
\hline & Risk likelihood & Risk severity & Alternative priority weigh & & & \\
\hline Weigh & 0.57 & 0.43 & & & & \\
\hline Time & 0.21 & 0.23 & 0.22 & & & \\
\hline Cost & 0.61 & 0.58 & 0.60 & & & \\
\hline Quality & 0.18 & 0.19 & 0.18 & & & \\
\hline
\end{tabular}




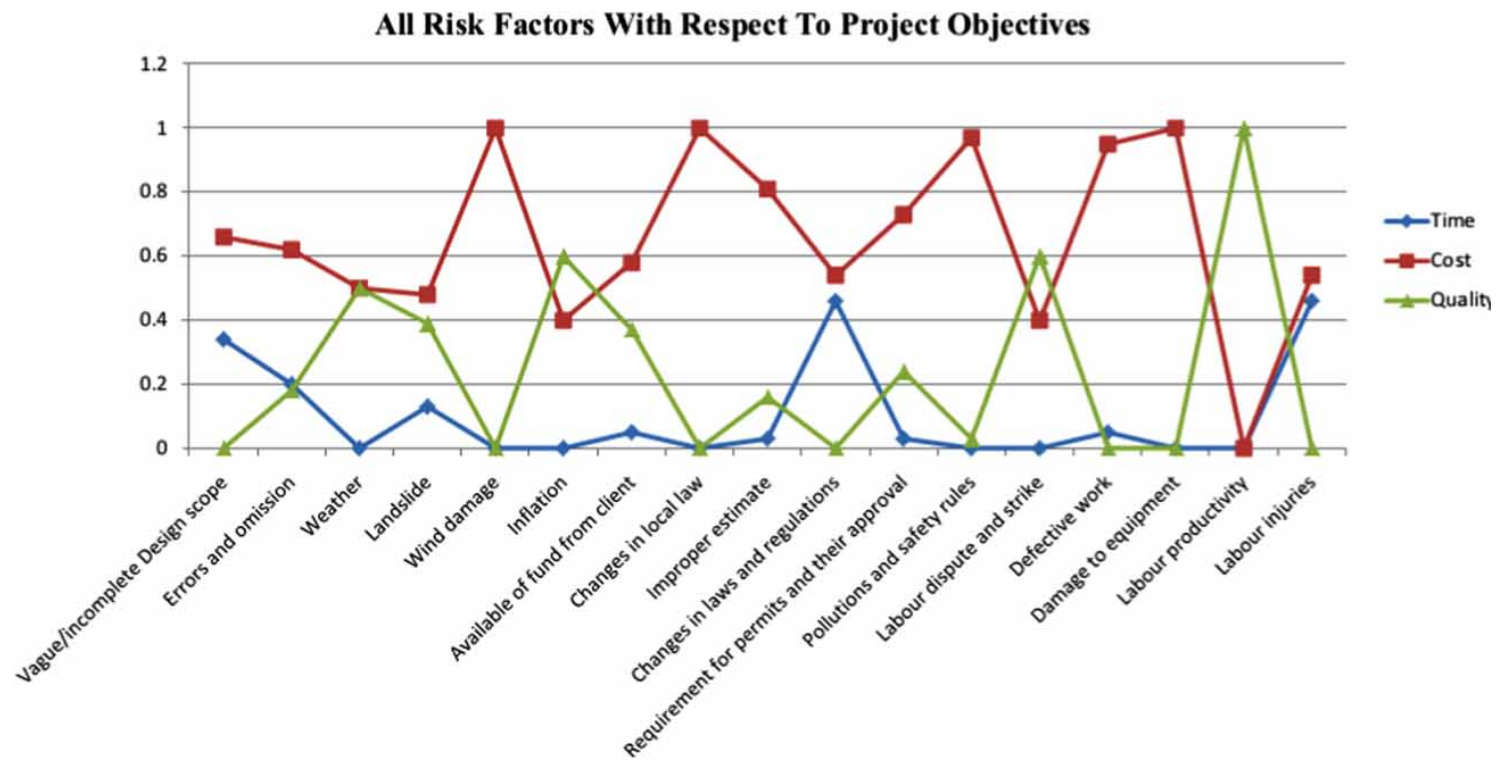

Fig. 5. All risk factors with respect to time, cost, and quality

Using these vectors, Eqs (9) to (12) were used to obtain the degree of possibility. The results are:

$$
\begin{aligned}
& V\left(S_{\text {Time }} \geq S_{\text {Cost }}\right)=0 ; \\
& V\left(S_{\text {Time }} \geq S_{\text {Quality }}\right)=0 ; \\
& V\left(S_{\text {Cost }} \geq S_{\text {Time }}\right)=1 ; \\
& V\left(S_{\text {Cost }} \geq S_{\text {Quality }}\right)=1 ; \\
& V\left(S_{\text {Quality }} \geq S_{\text {Time }}\right)=1 ; \\
& V\left(S_{\text {Quality }} \geq S_{\text {Cost }}\right)=1 .
\end{aligned}
$$

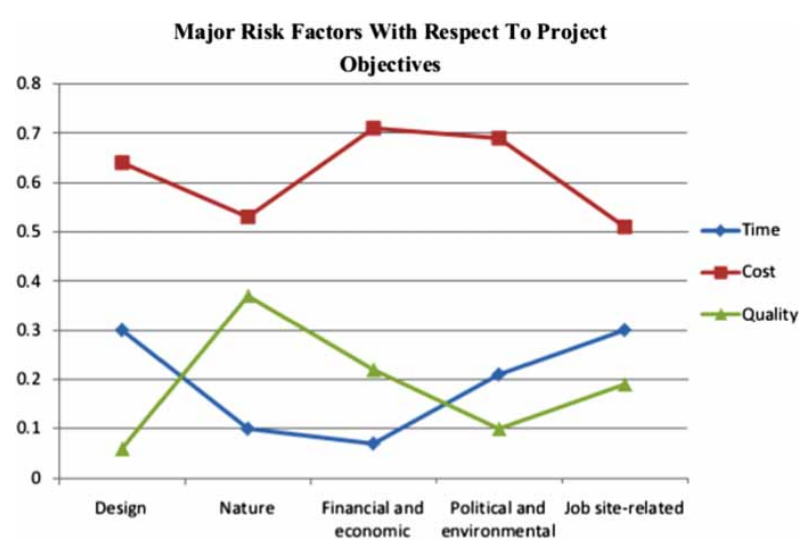
lated as:

Similarly, using Eq. (13), the results were calcu-

Fig. 6. Major risk factors with respect to time, cost, and quality

$$
\begin{aligned}
& V\left(S_{\text {Time }} \geq S_{\text {Cost },} S_{\text {Quality }}\right)=V\left(S_{\text {Time }} \geq S_{\text {Cost }} \text { and } S_{\text {Time }} \geq S_{\text {Quality }}\right)=0 \\
& V\left(S_{\text {Cost }} \geq S_{\text {Time }}, S_{\text {Quality }}\right)=V\left(S_{\text {Cost }} \geq S_{\text {Time }} \text { and } S_{\text {Cost }} \geq S_{\text {Quality }}\right)=1 \\
& V\left(S_{\text {Quality }} \geq S_{\text {Time }}, S_{\text {Cost }}\right)=V\left(S_{\text {Quality }} \geq S_{\text {Cost }} \text { and } S_{\text {Quality }} \geq S_{\text {Cost }}\right)=1 .
\end{aligned}
$$

Given by Eqs (14) and (15), the weigh vector is $W_{w}{ }^{\prime}=(0,1,1)^{T}$. Finally, via normalization of $W_{w}{ }^{\prime}$, the normalized weigh vector from Table 6 was calculated by using Eq. (16) as $W_{w}=(0,0.5,0.5)^{T}$, where $W_{w}$ are non-fuzzy numbers. This step was repeated for each criterion at each level in the hierarchy tree to derive their normalized weigh vectors. The matrices of pairwise comparisons and their respective normalized weigh vector at level 4 , level 3, level 2, and level 1 are presented in Tables 7, 8, 9 , and 10 , respectively.

\subsection{Pilot Run: synthesized final results}

Finally, the combination of priority weighs for each criterion at all levels were computed to determine overall priority weighs for the risks with respect to time, cost, and quality. The synthesized results are given in Table 11. The graphic results as shown in Figs 5 and 6 indicate that the project has higher risk in cost than in time and quality. Mitigation plan could then be executed to monitor and to control those risks with a high ranking to ensure their accordance with project objectives. 
Table 12. Validation results of FSM

\begin{tabular}{|c|c|c|c|c|c|c|c|}
\hline Evaluator & Flexibility & Accessibility & Completeness & Reliability & $\begin{array}{l}\text { User } \\
\text { Friendly }\end{array}$ & $\begin{array}{c}\text { Assistance in Decision- } \\
\text { making }\end{array}$ & $\begin{array}{l}\text { Adaptability for } \\
\text { complexity }\end{array}$ \\
\hline A & 7 & 8 & 8 & 9 & 9 & 10 & 10 \\
\hline B & 9 & 8 & 7 & 8 & 9 & 9 & 9 \\
\hline $\mathrm{C}$ & 8 & 7 & 8 & 10 & 10 & 9 & 10 \\
\hline $\mathrm{D}$ & 8 & 7 & 9 & 8 & 9 & 8 & 9 \\
\hline $\mathrm{E}$ & 7 & 8 & 9 & 10 & 10 & 10 & 10 \\
\hline $\mathrm{F}$ & 7 & 7 & 9 & 9 & 10 & 9 & 10 \\
\hline G & 9 & 9 & 8 & 9 & 9 & 9 & 10 \\
\hline $\mathrm{H}$ & 8 & 7 & 7 & 8 & 9 & 10 & 9 \\
\hline I & 8 & 8 & 9 & 10 & 9 & 9 & 10 \\
\hline MEAN & 7.9 & 7.7 & 8.2 & 9.0 & 9.3 & 9.2 & 9.7 \\
\hline
\end{tabular}

\subsection{Validation of FSM}

A validation process of the developed FSM was carried out to determine whether this model was of application value for risk evaluation in construction practices, which was conducted online by randomly selected 9 practitioners in the construction sector worldwide. Each parameter was given a 10 -scale evaluation. The validation results as shown in Table 12 indicate that the developed FSM could systematically help practitioners to evaluate construction risks. The values of flexibility, accessibility, completeness, reliability, user friendly level, assistance in decision-making, and adaptability for complexity are acceptable.

\section{Benefits and limitations}

The advantage of a Fuzzy-AHP model is that it could efficiently quantify the valuable subjective data to cope with multiple contradicting risk problems. Taking project objectives such as time, cost, and quality into consideration are very important in the risk assessment process. As to guarantee project success, it entails effective risk management of a project. Compared with those existing methods, the FSM developed in this study has the following benefits: a) it accelerates the decision-making process. Construction practitioners could conduct a complicated risk assessment process effectively using the developed model which is simple and systematic in evaluation and computation; b) it gives more convincing result with the consideration of project objectives within the framework, hence it aids in an optimal allocation of project resources to mitigate possible risks detrimental to the success of a project in terms of time, cost, and quality; c) it is able to capture the vagueness of human thinking style and to ensure the consistency in multi-criteria decisionmaking process; and d) it could be used in measuring risks across different stages of a project life cycle, from the inception till the completion of a project. Nevertheless, the developed FSM has a shortcoming that the computational fuzzy calculations in this model are rather time-consuming, which needs to be optimized in future study.

\section{Conclusions and recommendations}

Aiming to remove complex and unreliable process arising in subjective judgments during construction risk assessments, the developed FSM provides an appropriate approach to tackle the fuzziness involved in the decision-making process. The pilot run revealed that the FSM could accelerate the decision-making process and could provide optimal allocation of project resources to mitigate possible risks detrimental to the success of a project in terms of time, cost, and quality. Further efforts are recommended in developing a decision support tool to conduct the tedious fuzzy calculations to facilitate the overall risk assessment process. Besides, since the computational fuzzy calculations in the developed model is rather timeconsuming, the simplification and the optimization of the fuzzy calculation process should be paid attention to in future research works.

\section{References}

Ahmed, A.; Kayis, B.; Amornsawadwatana, S. 2007. A review of techniques for risk management in projects, Benchmarking: an International Journal 14(1): 22-36. http://dx.doi.org/10.1108/14635770710730919.

An, M.; Baker, C.; Zeng, J. 2005. A fuzzy-logic-based approach to qualitative risk modelling in the construction process, World Journal of Engineering 2(1): 1-12.

Baccarini, D.; Archer, R. 2001. The risk ranking of projects: a methodology, International Journal of Project Management 19(3): 139-145.

http://dx.doi.org/10.1016/S0263-7863(99)00074-5.

Baloi, D.; Price, A. D. F. 2003. Modelling global risk factors affecting construction cost performance, International Journal of Project Management 21(4): 261-269. http://dx.doi.org/10.1016/S0263-7863(02)00017-0.

Berkeley, D.; Humphreys, P. C.; Thomas, R. D. 1991. Project risk action management, Construction Management and Economics 9(1): 3-17. http://dx.doi.org/10.1080/01446199100000002. 
Bojadziev, G.; Bojadziev, M. 2007. Fuzzy logic for business, finance, and management. $2^{\text {nd }}$ ed. Singapore: World Scientific. $232 \mathrm{p}$.

Buckley, J. J. 1985. Fuzzy hierarchical analysis, Fuzzy Sets and Systems 17(3): 233-247. http://dx.doi.org/10.1016/0165-0114(85)90090-9.

Cagno, E.; Caron, F.; Mancini, M. 2007. A multi-dimensional analysis of major risks in complex projects, Risk Management 9: 1-18. http://dx.doi.org/10.1057/palgrave.rm.8250014.

Chan, F. T. S.; Kumar, N. 2007. Global supplier development considering risk factors using fuzzy extended AHP-based approach, Omega 35(4): 417-431. http://dx.doi.org/10.1016/j.omega.2005.08.004.

Chang, D. Y. 1992. Extent Analysis and Synthetic Decision, Optimization Techniques and Applications. Vol. 1. Singapore: World Scientific.

Chang, D.-Y. 1996. Applications of the extent analysis method on Fuzzy-AHP, European Journal of Operational Research 95(3): 649-655. http://dx.doi.org/10.1016/0377-2217(95)00300-2.

Chang, Y.-H.; Yeh, C.-H.; Wang, S.-Y. 2007. A survey and optimization-based evaluation of development strategies for the air cargo industry, International Journal of Production Economics 106(2): 550-562. http://dx.doi.org/10.1016/j.ijpe.2006.06.016.

Chang, Y.-H.; Yeh, C.-H. 2002. A survey analysis of service quality for domestic airlines, European Journal of Operational Research 139(1): 166-177.

http://dx.doi.org/10.1016/S0377-2217(01)00148-5.

Chapman, C. B.; Cooper, D. F. 1983. Risk analysis: testing some prejudices, European Journal of Operational Research 14(1): 238-247. http://dx.doi.org/10.1016/0377-2217(83)90260-6.

Chen, C.-T.; Huang, S.-F. 2006. Order-fulfilment ability analysis in the supply-chain system with fuzzy operation times, International Journal Production Economics 101(1): 185-193.

http://dx.doi.org/10.1016/j.ijpe.2005.05.003.

Chen, S.-P.; Hsueh, Y.-J. 2007. A simple approach to fuzzy critical path analysis in project networks, Applied Mathematical Modelling 32(7): 1289-1297. http://dx.doi.org/10.1016/j.apm.2007.04.009.

Chen, S.-M. 2001. Fuzzy group decision making for evaluating the rate of aggregative risk in software development, Fuzzy Sets and Systems 118(1): 75-88. http://dx.doi.org/10.1016/S0165-0114(99)00103-7.

Cheng, M.-Y.; Tsai, H.-C.; Sudjono, E. 2010. Evolutionary fuzzy hybrid neural network for project cash flow control, Engineering Applications of Artificial Intelligence 23(4): 604-613. http://dx.doi.org/10.1016/j.engappai.2009.10.003.

Cho, H.-M.; Choi, H.-H.; Kim, Y.-K. 2002. A risk assessment methodology for incorporating uncertainties using fuzzy concepts, Reliability Engineering \& System Safety 78(2): 173-183. http://dx.doi.org/10.1016/S0951-8320(02)00158-8.

Choi, H.-H.; Cho, H.-N.; Seo, J. W. 2004. Risk assessment methodology for underground construction projects, Journal of Construction Engineering and Management ASCE 130(2): 258-272. http://dx.doi.org/10.1061/ (ASCE)0733-9364(2004)130:2(258).
Chun, M.-H.; Ahn, K.-II. 1992. Assessment of the potential application of fuzzy set theory to accident progression event trees with phenomenological uncertainties, Reliability Engineering \& System Safety 37(3): 237-252. http://dx.doi.org/10.1016/0951-8320(92)90130-D.

Cioffi, D. F.; Khamooshi, H. 2009. A practical method of determining project risk contingency budgets, Journal of the Operational Research Society 60: 565-571. http://dx.doi.org/10.1057/palgrave.jors. 2602586.

Cooper, D. F.; Chapman, C. B. 1987. Risk analysis for large projects: models, methods, and cases. New York: John Willey. $260 \mathrm{p}$.

Cooper, D. F.; MacDonald, D. H.; Chapman, C. B. 1985. Risk analysis of a construction cost estimate, International Journal of Project Management 3(3): 141-149. http://dx.doi.org/10.1016/0263-7863(85)90065-1.

Dağdeviren, M.; Yüksel, I. 2008. Developing a fuzzy analytic hierarchy process model for behaviour-based safety management, Information Sciences 178(6): 1717-1733. http://dx.doi.org/10.1016/j.ins.2007.10.016.

Dey, P.; Tabucanon, M. T.; Ogunlana, S. 1994. Planning for project control through risk analysis: a petroleum pipeline-laying project, International Journal of Project Management 12(1): 23-33. http://dx.doi.org/10.1016/0263-7863(94)90006-X.

Dey, P. K. 2001. Decision support system for risk management: a case study, Management Decision 39(8): 634-649. http://dx.doi.org/10.1108/00251740110399558.

Diekmann, J. E. 1992. Risk analysis: lessons from artificial intelligence, International Journal of Project Management 10(2): 75-80. http://dx.doi.org/10.1016/0263-7863(92)90059-I.

Dikmen, I.; Birgonul, M. T.; Gur, K. 2007a. A case-based decision support tool for bid mark-up estimation of international construction projects, Automation in Construction 17(1): 30-44. http://dx.doi.org/10.1016/j.autcon.2007.02.009.

Dikmen, I.; Birgonul, M. T.; Han, S. 2007b. Using fuzzy risk assessment to rate cost overrun risk in international construction projects, International Journal of Project Management 25(5): 494-505. http://dx.doi.org/10.1016/j.ijproman.2006.12.002.

Ding, J.-F.; Liang, G.-S. 2005. Using fuzzy MCDM to select partners of strategic alliances for liner shipping, Information Sciences 173(1-3): 197-225. http://dx.doi.org/10.1016/j.ins.2004.07.013.

Dweiri, F. T.; Kablan, M. M. 2006. Using fuzzy decision making for the evaluation of the project management internal efficiency, Decision Support Systems 42(2): $712-726$ http://dx.doi.org/10.1016/j.dss.2005.04.001.

Flanagan, R.; Norman, G. 1993. Risk management and construction. Victoria, Australia: Blackwell Science Pty Ltd. $224 \mathrm{p}$.

Franceschini, F.; Galleto, M. 2001. A new approach for evaluation of risk priorities of failure modes in FMEA, International Journal of Production Research 39(13): 2991-3002. http://dx.doi.org/10.1080/00207540110056162

Han, S. H.; Kim, D. Y.; Kim, H.; Jang, W.-S. 2008. A webbased integrated system for international project risk 
management, Automation in Construction 17(3): 342356.

http://dx.doi.org/10.1016/j.autcon.2007.05.012.

Hastak, M.; Shaked, A. 2000. ICRAM-1: model for international construction risk assessment, Journal of Management in Engineering ASCE 16(1): 59-69. http://dx.doi.org/10.1061/(ASCE)0742-597X(2000) $16: 1(59)$

Heshmaty, B.; Kandel, A. 1985. Fuzzy linear regression and its applications to forecasting in uncertain environment, Fuzzy Sets and Systems 15(2): 159-191. http://dx.doi.org/10.1016/0165-0114(85)90044-2.

Huang, D.; Chen, T.; Wang, M.-J. J. 2001. A fuzzy set approach for event tree analysis, Fuzzy Sets and Systems 118(1): 153-165. http://dx.doi.org/10.1016/S0165-0114(98)00288-7.

Idrus, A.; Nuruddin, M. F.; Rohman, M. A. 2011. Development of project cost contingency estimation model using risk analysis and fuzzy expert system, Expert Systems with Applications 38(3): 1501-1508. http://dx.doi.org/10.1016/j.eswa.2010.07.061

Jannadi, O. A.; Almishari, S. 2003. Risk assessment in construction, Journal of Construction Engineering and Management 129(5): 492-500. http://dx.doi.org/10. 1061/(ASCE)0733-9364(2003)129:5(492).

Kahraman, C.; Cebeci, U.; Ruan, D. 2004. Multi-attribute comparison of catering service companies using Fuzzy-AHP: the case of Turkey, International Journal of Production Economics 87(2): 171-184. http://dx.doi.org/10.1016/S0925-5273(03)00099-9.

Kangari, R.; Riggs, L. S. 1989. Construction risk assessment by linguistics, IEEE Transitions on Engineering Management 36(2): 126-131. http://dx.doi.org/10.1109/17.18829.

Karsak, E. E.; Tolga, E. 2001. Fuzzy multi-criteria decisionmaking procedure for evaluating advanced manufacturing system investments, International Journal of Production Economics 69(1): 49-64.

Kasabov, N. K. 1996. Foundation of neural network: fuzzy systems and knowledge engineering. MIT Press. 568 p.

Latham, M. 1994. Constructing the Team, Final Report of the Government/Industry Review of Procurement and Contractual Arrangements in The UK Construction Industry. London: HMSO. $140 \mathrm{p}$.

Lee, H. M.; Lin, L. 2010. A new fuzzy risk assessment approach, in Proc. of Knowledge-Based and Intelligent Information and Engineering Systems: 14th International Conference, KES 2010, 8-10 September, 2010, Cardiff, UK, 98-105.

Lyons, T.; Skitmore, M. 2004. Project risk management in the Queensland engineering construction industry: a survey, International Journal of Project Management 22(1): 51-61.

Mustafa, M. A.; Al-Bahar, J. F. 1991. Project risk analytic assessment using the Hierarchy Process, IEEE Transactions on Engineering Management 38(1): 46-52.

Mulholland, B.; Christian, J. 1999. Risk assessment in construction schedules, Journal of Construction Engineering and Management ASCE 125(1): 8-15.

Nieto-Morote, A.; Ruz-Vila, F. 2011. A fuzzy approach to construction project risk assessment, International Journal of Project Management 29(2): 220-231.
Naeni, L. M.; Shadrokh, S.; Salehipour, A. 2011. A fuzzy approach for the earned value management, International Journal of Project Management 29(6): 764-772.

Negnevitsky, M. 2004. Artificial intelligence: a guide to intelligent systems. $2^{\text {nd }}$ ed. London, UK: AddisonWesley. $440 \mathrm{p}$.

Nguyen, V. U. 1985. Tender evaluation by fuzzy sets, Journal of Construction Engineering and Management ASCE 111(3): 231-243.

Paek, J. H.; Lee, Y. W.; Ock, J. H. 1993. Pricing construction risks: fuzzy set theory, Journal of Construction Engineering and Management ASCE 119(4): 743-756.

Pedrycz, W. 1994. Why triangular membership functions? Fuzzy Sets and Systems 64(1): 21-30.

Riggs, J. L.; Brown, S. B.; Trueblood, R. B. 1994. Integration of technical, cost and schedule risks in project management, Computers \& Operations Research 21(5): 521533.

Saaty, T. L. 1980. The analytic hierarchy process. New York: McGraw-Hill. 281 p.

Saaty, T. L. 1990. How to make a decision: the analytic hierarchy process, European Journal of Operational Research 48(1): 9-26.

Shang, H.; Anumba, C. J.; Bouchlaghem, D. M.; Miles, J. C.; Cen, M.; Taylor, M. 2005. An intelligent risk assessment system for distributed construction teams, Engineering, Construction and Architectural Management 12(4): 391-409.

Sii, H. S.; Wang, J. 2003. A design-decision support framework for evaluation of design options/proposals using a composite structure methodology based on the approximate reasoning approach and reasoning method, in Proc. of the Institution of Mechanical Engineers 217(1): 59-76.

Sun, Y.; Huang, R.; Chen, D.; Li, H. 2008. Fuzzy Set-based risk evaluation model for real estate projects, Tsinghua Science and Technology 13(S1): 158-164.

Tah, J. H. M.; Carr, V. 2000. A proposal for construction project risk assessment using fuzzy logic, Construction Management and Economics 18(4): 491-500.

Tah, J. H. M.; Carr, V. 2001. Knowledge-Based approach to construction project risk management, Journal of Computing in Civil Engineering ASCE 15(3): 170-177.

Tavares, L. V.; Ferreira, J. A. A.; Coehlo, J. S. 1998. On the optimal management of project risk, European Journal of Operational Research 107: 415-469.

Thomas, A. V.; Kalidindi, S. N.; Ganesh, L. S. 2006. Modeling and assessment of critical risks in BOT road projects, Construction Management and Economics 24(4): 407-424.

van Laarhoven, P. J. M.; Pedrycz, W. 1983. A fuzzy extension of Saaty's priority theory, Fuzzy Sets and Systems 11(1-3): 199-227.

Wang, S. Q.; Dulaimi, M. F.; Aguria, M. Y. 2004. Risk management framework for construction projects in developing countries, Construction Management and Economics 22(3): 237-252.

Wang, Y.-M.; Elhag, T. M. S. 2007. A fuzzy group decision making approach for bridge risk assessment, Computers \& Industrial Engineering 53(1): 137-148. 
Ward, S.; Chapman, C. 2003. Transforming project risk management into project uncertainty management, International Journal of Project Management 21(2): 97-105.

Wei, C.-C.; Liang, G.-S.; Wang, M.-J. J. 2007. A comprehensive supply chain management project selection framework under fuzzy environment, International Journal of Project Management 25(6): 627-636.

Williams, T. M. 1995. A classified bibliography of recent research relating to project risk management, European Journal of Operational Research 85(1): 18-38.

Wirba, E. N.; Tah, J. H. M.; Howes, R. 1996. Risk interdependencies and natural language computations, Engineering, Construction and Architectural Management 3(4): 251-269.

Xu, Z.-S.; Chen, J. 2007. An interactive method for fuzzy multiple attribute group decision making, Information Sciences 177(1): 248-263.

Yager, R. R. 2002. Uncertainty representation using fuzzy measures, IEEE Transactions on Systems, Man, and Cybernetics, Part B: Cybernetics 32(1): 20-28.

Yeo, K. T. 1990. Risks, classification of estimates and contingency, Journal of Management Engineering 6(4): 458-470.

Zadeh, L. A. 1965. Fuzzy sets, Information and Control 8(3): 338-353.

Zadeh, L. A. 1978. Fuzzy sets as a basis for a theory of possibility, Fuzzy Sets and Systems 1(1): 3-28.

Zavadskas, E. K.; Turskis, Z.; Tamosaitiene, J. 2010. Risk assessment of construction projects, Journal of Civil Engineering and Management 16(1): 33-46.

Zayed, T.; Amer, M.; Pan, J. 2008. Assessing risk and uncertainty inherent in Chinese highway projects using
AHP, International Journal of Project Management 26(4): 408-419.

Zeng, J.; An, M.; Smith, N. J. 2007. Application of a fuzzy based decision making methodology to construction project risk assessment, International Journal of Project Management 25(6): 589-600.

Zhang, H. 2007. A redefinition of the project risk process: using vulnerability to open up the event consequence link, International Journal of Project Management 25(7): 694-701.

Zhang, G.; Zou, P. X. 2007. Fuzzy analytical hierarchy process risk assessment approach for joint venture construction projects in China, Journal of Construction Engineering and Management ASCE 133(10): 771-779.

Zhang, H.; Dong, Y.; Li, M.; Sun, Z. 2002. Research for application of group decision method on appraisement system of science research schema, in Proc. of the 4th World Congress on Intelligent Control and Automation, 10-14 June, 2002, Shanghai, China, 602-606.

Zheng, D. X. M.; Ng, T. 2005. Stochastic time-cost optimization model incorporating fuzzy sets theory and non-replacement, Journal of Constructing Engineering and Management ASCE 131(2): 176-186.

Zhi, H. 1995. Risk management for overseas construction, International Journal of Project Management 13(4): 231-237.

Zieliński, P. 2005. On computing the latest starting times and floats of activities in a network with imprecise durations, Fuzzy Sets Systems 150(1): 53-76.

Hamzah ABDUL-RAHMAN. Professor Dr Dip. Bldg (UiTM), BSc (Hons) Central Missouri State University, MSc University of Florida, PhD University of Manchester Institute of Science and Technology, FRICS, MCIOB, MIVMM, is currently the Deputy Vice Chancellor (Research \& Innovation), University of Malaya and a full professor in the Faculty of Built Environment, University of Malaya. He has served as the Deputy Vice Chancellor for Development and Estate Management in charge of development policies and construction projects from 1996 to 2003, and the Deputy Vice Chancellor (Academic \& International) from 2009-2010 in University of Malaya. He holds a PhD degree from the University of Manchester Institute of Science and Technology (UMIST, UK), M.Sc. from University of Florida and BSc (Hons) from Central Missouri State University, Dip. Bldg (UiTM). His research interests include the construction innovation \& sustainability, project \& facility management, building energy efficiency, industrialized building system (IBS), and renewable energy application in buildings, supported by his vast publications. He is also a fellow member of the Chartered Institute of Surveyors, United Kingdom (International).

Chen WANG. Dr, senior Lecturer of Construction Innovation and Project Management in the Faculty of Built Environment, University of Malaya. He was a senior engineer of China State Construction Engineering Corporation (CSCEC). His research interests include Mathematics Modeling for Civil Engineering, Fuzzy-QFD, the sustainability in construction management, international BOT projects, energy conservation, and building integrated solar application, supported by his vast publications. He is also a perpetual member of The Chinese Research Institute of Construction Management (CRIOCM), Hong Kong (International).

Yee Lin LEE. Research fellow in the Center of Construction Facility Management, Faculty of Built Environment, University of Malaya. Her expertise is in Fuzzy Logic Computing, Fuzzy Quality Function Deployment, and Building Physics. 